\title{
ine \\ Online Wind-Atlas Databases and GIS Tool Integration for Wind Resource Assessment: A Spanish Case Study
}

\author{
Agustín Sánchez-del Rey ${ }^{1}$ (), Isabel Cristina Gil-García ${ }^{2}$, , María Socorro García-Cascales ${ }^{3}$ (D) \\ and Ángel Molina-García ${ }^{1, *(\mathbb{D})}$ \\ 1 Department of Automatics, Electrical Engineering and Electronic Technology, Universidad Politécnica de \\ Cartagena, 30202 Cartagena, Spain; agustin.sanchez@edu.upct.es \\ 2 Faculty of Engineering, Distance University of Madrid (UDIMA), 28400 Madrid, Spain; \\ isabelcristina.gil@udima.es \\ 3 Department of Electronics, Computer Architecture and Projects Engineering, Universidad Politécnica de \\ Cartagena, 30202 Cartagena, Spain; socorro.garcia@upct.es \\ * Correspondence: angel.molina@upct.es; Tel.: +34-968-32-54-62
}

check for

updates

Citation: Sánchez-del Rey, A.;

Gil-García, I.C.; García-Cascales, M.S.; Molina-García, Á. Online Wind-Atlas Databases and GIS Tool Integration for Wind Resource Assessment: A Spanish Case Study. Energies 2022, 15, 852. https://doi.org/10.3390/ en15030852

Academic Editors: Dalia Štreimikienè and Tomas Baležentis

Received: 16 December 2021

Accepted: 19 January 2022

Published: 25 January 2022

Publisher's Note: MDPI stays neutral with regard to jurisdictional claims in published maps and institutional affiliations.

Copyright: (c) 2022 by the authors. Licensee MDPI, Basel, Switzerland. This article is an open access article distributed under the terms and conditions of the Creative Commons Attribution (CC BY) license (https:// creativecommons.org/licenses/by/ $4.0 /)$.

\begin{abstract}
Renewable energy sources are becoming increasingly integrated into the electricity-generation sector, being eco-friendly solutions, decreasing global warming, and improving the energy transition process. Among the different renewables, wind energy is considered a mature, clean, renewable, and inexhaustible technology as well, becoming one of the main resources in a sustainable framework. Aiming to evaluate the wind resource, scientific contributions have mostly presented a common basis: historical data campaigns of the wind resource mainly considering wind speed-including the module, direction, standard deviation, etc. However, online wind-atlas databases are becoming tools widely used for both wind-resource assessment and optimal wind-power locations. Under this framework, this study analyzed and compared such online wind data sources and their integration with GIS tools for optimal wind-resource-assessment purposes. The proposed methodology identified the corresponding wind-atlas databases directly on their websites and indirectly through the wind data used in relevant contributions about the optimal location of wind sites. Our contribution to the scientific community is thus the review and comparison of these atlas databases for reducing the barrier to access wind data-including GIS-tool-integration analysis. The limitations raised by civil societies, particularly regarding environmental and bird concerns, were not included in this study. Nevertheless, the authors are aware of these concerns and limitations. A Spanish case study was also included in this work, comparing both estimated and collected wind-atlas databases in terms of wind-resource assessment.
\end{abstract}

Keywords: Geographic Information System (GIS); online database; wind atlas; wind-resource assessment

\section{Introduction}

Sustainable development is a major goal of worldwide policy [1]. Moreover, a sustainable world addresses renewable-energy-source integration into different sectors, leaving behind fossil-fuel energy sources, such as oil [2], coal [3], and gasoline [4], and decreasing large emissions [5,6]. Among the different renewables, wind energy is considered one of the strongest and most profitable resources [7-9]. The evolution of the global wind sector is upward, in the new MW added to the total capacity as electrical energy generated from wind-power plants. The onshore wind capacity has increased by $298 \%$, adding approximately $530 \mathrm{GW}$ in the 2010-2020 period. A total of $32 \mathrm{GW}$ has joined the total offshore capacity during this same period. The global accumulated wind capacity in 2020, including both technologies (on- and offshore), accounts for $743 \mathrm{GW}-\mathrm{a} 14 \%$ growth over the previous year. The new facilities exceed $92 \mathrm{GW}$, being the annual electricity generated 
close to 1648 TWh (see Figure 1) [10]. Previous wind-energy-evolution data analysis can be found in [11].

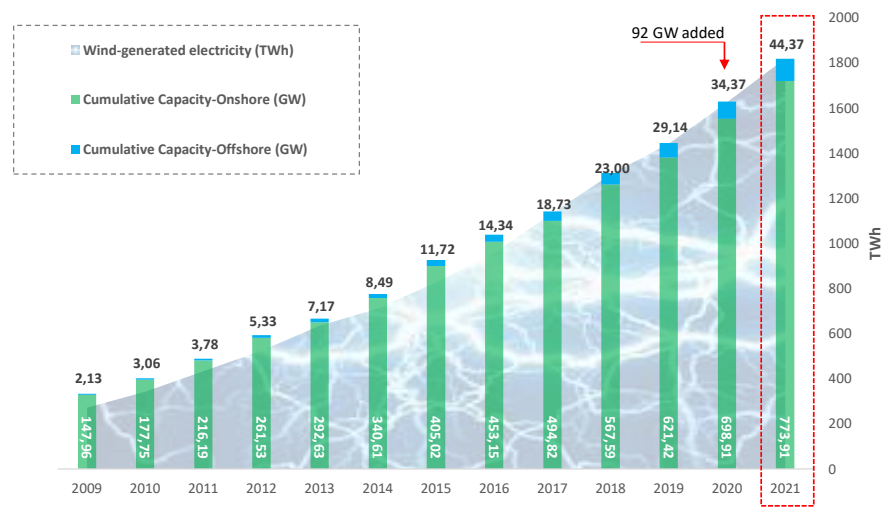

Figure 1. Accumulated and generated wind-energy evolution. Own elaboration.

Nedaei et al. [12] affirm that wind characterization is the first step to estimate the initial feasibility of wind-power generation, mainly based on the wind speed, the wind direction, and the available wind power. Moreover, the database is crucial for an optimal accuracy of wind-power forecasting [13]. Indeed, relevant forecasting approaches can be found in the specific literature by considering a variety of databases. Halil et al. [14] proposed long-term wind-speed forecasting using machine-learning algorithms and based on daily wind-speed data and the standard deviation from meteorological stations located in Turkey. Yang et al. [15] developed a hybrid forecasting and analysis system to perform wind-energy deterministic and probabilistic interval forecasting, using 10-minute wind data collected from a meteorological tower located in the Chengde wind-power plant (China). Based on wind-speed data from wind-power plants located in Spain and China, Zhang et al. [16] took advantage of the error information from the data series and proposed a two-stage forecasting system that performs a data pre-processing approach, with a multi-enhanced target-optimization algorithm, error correction, and a non-linear set strategy. Historical data from the Jeju Island wind-power plant in South Korea were used by Kim and Hur [17] for the purpose of forecasting short-term wind resources using the improved ensemble method. Fazelpour et al. [18] accurately estimated short-term wind-speed forecasting through artificial-intelligence methods. The basis of the method was historical data series provided by the Iran Renewable Energy Organization. Rezaeiha et al. [19] evaluated the urban potential of wind energy. This methodology incorporated the historical data of the wind speed on the roofs of the buildings categorized according to height. The data series were obtained from the Netherlands Enterprise Agency. Three years of averaged wind-speed historical data were collected in hourly intervals by Khchine et al. [20]. The wind potentials in two Moroccan cities were assessed using various methods, such as wind variability, power density, standard deviation, Moroccan methods, and WAsP to determine the Weibull parameters. The wind potential from a technical and economic point of view was evaluated by Bahrami et al. [21] at various locations in a city in Uzbekistan. One-year wind speed data were needed with hourly measurements at a height of $10 \mathrm{~m}$, obtained from meteorological stations. The wind potential of the city of Tuvalu was assessed by Talama et al. [22] through one-year wind data at heights of 24 and $30 \mathrm{~m}$. Various methods were used to find the Weibull parameters and to determine the power density. Sumair et al. [23] evaluated the wind potential in southern Punjab from five-year wind data with hourly measurements at a height of $50 \mathrm{~m}$, collected from the Pakistan Meteorological Department. In summary, the most-cited works use simulation and forecasting techniques to address issues about wind-power potential, power system operations, or planning for disconnection (or connection) of wind turbines [24]. 
Numerous researchers have proposed optimization-based solutions in the evaluation and selection of wind-power plants around the world: Thailand [25], Turkey [26], Nigeria [27], Saudi Arabia [28], Spain [29,30], Europa [31], Mexico [32], United Kingdom [33], etc. In general, the profitability of wind-power installations is associated with a set of factors from different categories, with wind speed being the most determining factor [34]. Therefore, it is crucial to use reliable data campaigns, usually involving several year periods, to characterize both seasonal and annual wind-speed variations, aiming to evaluate accurately the wind-resource potential [11]. Nowadays, the use of satellite remote-sensing tools in a variety of sectors is of primary interest. A recent review on wind, geothermal, biomass, and wave sources assessment by using Synthetic Aperture Radar satellite (Sentinel-1) estimation can be found in [35]. A Modern-Era Retrospective Analysis for Research and Applications (MERRA) reanalysis dataset was initially conducted by the National Aeronautics and Space Administration (NASA) Center to give long-term wind data covering the world spatially. It was subsequently reconstructed according to an upgraded version of the Goddard Earth Observing System Model with a $50 \times 50 \mathrm{~km}$ spatial resolution [36]. Yue et al. [37] evaluated wind resources by using on-ground station data, mast and floating light detection and ranging (LiDAR), and MERRA. Similar evaluation studies can be found in [38-42]. Nevertheless, and despite the fact that the starting point for most of these contributions is a historical wind-data campaign with some variables under different formats (quantitative and spatial), only a few works focus on characterizing and comparing online wind-atlas databases currently available in the specific literature for the researcher community [43]. In this context, this study aimed to describe and compare such wind atlases available online, discussing their main indicators-wind data, data collection height, sample time, etc. These wind atlases were selected through direct identification on the websites or indirect identification through scientific contributions published during the last decade. Geographic Information Systems (GIS) tool integration was also included in this work, to evaluate the potential combination of these wind atlases with such GIS tools. Moreover, and according to Tammelin et al. [44], more-accurate wind atlases are demanded for potential identification of optimal wind-power plant sites. The rest of the article is structured as follows: Section 2 describes the methodology used in this analysis; Section 3 presents the results of the data-source identification; Section 4 characterizes and compares the wind data sources; Section 5 discusses the data integration with GIS tools; Section 6 analyzes and discusses the main results. Finally, Section 7 provides the conclusions.

\section{Methodology}

A methodology based on the "Preferred Reporting Items for Systematic Reviews and Meta-Analyses" (PRISMA) [45] was selected by the authors. Systematic reviews allow researchers to study many sources with precision to determine the most appropriate of them. Figure 2 shows an overview of the proposed methodology.

Systematic review: The objective of this stage was to identify the wind data sources in two ways: (i) Directly on the web and (ii) through the contributions by means of identifying such wind data sources used by researchers in their work methodologies for wind-data forecasting studies, wind-resource-potential discussion, or wind site optimization. Both pathways were grouped into the following steps: Detection, screening, and eligibility, and they were included. First, data sources were identified with meteorological variables using the Google search engine. Subsequently, sources that did not include wind variables were discarded. Sources providing free access to wind data were included in this study as well. The contribution databases used were the following: Google Scholar, ScienceDirect, SCOPUS, and Web of Science. From the keywords of the objectives derived from the analyzed topic, all relevant contributions were initially identified. Subsequently, from the contributions related to the specific problem, duplicate records and unrelated works were discarded, identifying the group of potential contributions. The full text of these selected works was then reviewed, discarding such reviews and/or works not directly related to 
the wind resource. Finally, the selected contributions to the study were considered for analysis purposes.

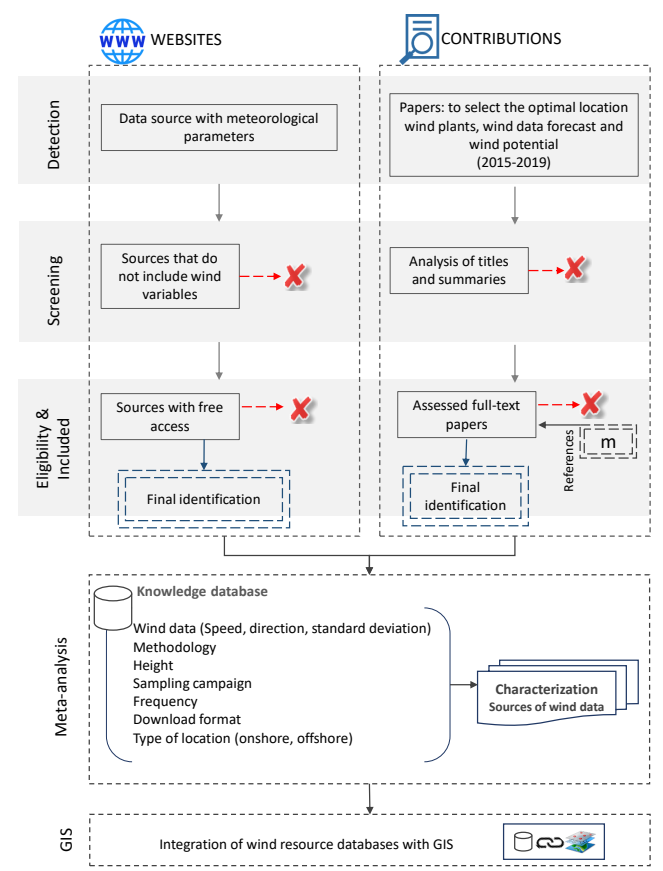

Figure 2. Proposed methodology. Systematic reviews and meta-analyses. Own elaboration.

Meta-analysis: Two steps were involved in this process: (i) Proposal for a database of wind data sources based on the sources identified directly and indirectly — the fields and their description are shown in Table 1-and (ii) characterization of wind data sources.

Table 1. Knowledge database. Fields.

\begin{tabular}{ll}
\hline Field & Description \\
\hline Wind data & Wind variables that can be obtained: wind speed, direction, and typical deviation \\
Methodology & Procedure used to obtain wind variables and identify data truthfulness \\
& It is necessary to know the procedure used to obtain wind variables \\
Height & Height suitable for the wind turbine nacelle to be placed \\
Sampling campaign & A higher number of period available, facilitating wind-resource analysis \\
Frequency & Reducing uncertainty, giving accurate estimations \\
Download format & Text, csv format, spreadsheet \\
Type of location & Onshore, offshore or both \\
\hline
\end{tabular}

Geographic Information Systems: Geographic Information Systems (GIS) are closely related to solve spatial problems in different areas: Business, managerial, or scientific areas. Given the importance of GIS integration into the wind-power sector, the wind data sources allowing such GIS integration were then analyzed and included in this article.

\section{Systematic Reviews}

By using the Google search engine, 32 data sources with meteorological variables were initially identified. After a preliminary analysis, 18 data sources were discarded, since they did not include wind variables. Finally, eight data sources providing free access to wind data were selected and included in this work. Given the strong relationship between the use of wind data sources and the methodologies of wind-data forecasting studies, as well as the wind potential of a study area and the optimal selection of wind sites, the second approach involved analyzing the contributions obtained from a previous work in recent years (2015-2019). 
From the keywords of the objectives derived from the searching of contributions, a total of 3133 works were identified. After a first analysis, 375 potential contributions were selected, and 2758 were discarded due to duplicate records and/or external works. The full text of the selected works was reviewed, discarding such reviews and studies not directly related to wind resources. Finally, 97 contributions were included in the study, while 284 were discarded, and six contributions from other references were added. In summary, $40 \%$ of the works used wind data sources from meteorological stations, ocean buoys, and information from ports and institutions in the country of the study case; $31 \%$ of researchers used wind data sources online with free access at a global or a continental level. The databases for both identifications were: Global Wind Atlas, NREL, FINO, and NASA Power Larc, accounting for $18 \%$. During the contribution analysis, two new databases were added to the results: ECMWF and NOAA (see Figure 3. The wind data sources found by both methods are summarized in Table 2.

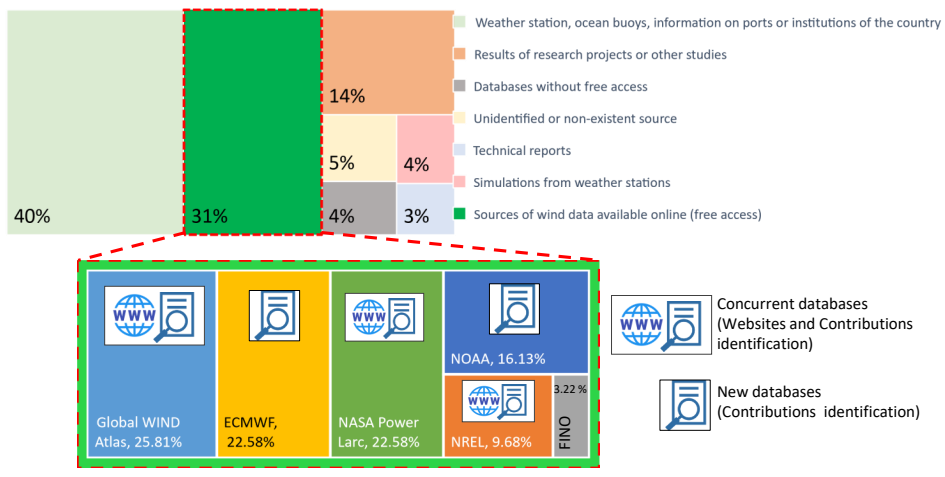

Figure 3. Results of the identification by contributions, and comparison with identification by website. Own elaboration.

Table 2. Wind data sources. Website (WI) and contribution (CI) identification.

\begin{tabular}{|c|c|c|c|c|}
\hline \multirow{2}{*}{ Source } & \multicolumn{2}{|c|}{ Type } & \multirow{2}{*}{ Website } & \multirow{2}{*}{ Contribution } \\
\hline & WI & CI & & \\
\hline Weather station, ocean buoys, & & & & \\
\hline information on ports or institutions of the country & & $X$ & & {$[17,25,27-29,32,46-60,60-76]$} \\
\hline Results of research projects or other studies & & $X$ & & [77-85] \\
\hline Databases without free access & & $X$ & & {$[33,86-88]$} \\
\hline Unidentified or non-existent source & & $X$ & & {$[64,89-92]$} \\
\hline Technical reports & & $X$ & & [92-94] \\
\hline Simulations from weather stations & & $X$ & & [95-98] \\
\hline ECMWF & & $X$ & [99] & {$[31,100-102,102-108]$} \\
\hline NOAA & & $X$ & [109] & [110-114] \\
\hline NEWA & $X$ & & [115] & \\
\hline Vortex & $X$ & & [116] & \\
\hline Renewables.Ninja & $X$ & & [117] & \\
\hline WindFinder & $x$ & & [118] & \\
\hline Global Wind Atlas & $X$ & $X$ & [119] & {$[85,120-123]$} \\
\hline NREL & $X$ & $X$ & [124] & [125-127] \\
\hline FINO & $X$ & $X$ & [128] & [129] \\
\hline NASA Power Larc & $X$ & $X$ & [130] & {$[107,108,122,123,131-133]$} \\
\hline
\end{tabular}

\section{Meta-Analysis}

From the preliminary data sources summarized in Table 2, 10 open-access windresource databases were described and compared, as follows. 


\subsection{Characterization of Wind Data Sources}

ECMWF: The European Center for Medium-Range Weather Forecasts produces global numerical weather forecasts for users around the world [99]. They are available for member and cooperating states, as well as through licensing to the World Meteorological Organization (WMO). By using their meteorological model and observing framework, ECMWF technically supports the EU-funded Copernicus program and provides high-quality information on climate change. Their polar-orbiting satellite, called "Aeolus," sends laser light into the atmosphere and measures the backscatter to obtain information on winds in the orthogonal direction to the satellite's path. They offer a wide catalog of available parameters, such as temperature, the probability of snow, rainfall, and the wave height. Focused on wind data available for free access, it is only possible to download the wind speed and the direction for 10 and $30 \mathrm{~m}$ above the surface. Data can be downloaded from:

- $\quad$ ERA5: Available from 1979 to within the last five days, providing hourly estimations of a relevant number of atmospheric, oceanic, and land climate data. Such data cover the Earth through a $30 \mathrm{~km}$ grid and resolve the atmosphere from the surface up to a height of $80 \mathrm{~km}$ subdividing into a series of 137 levels. A recent ERA5 reanalysis data reliability for wind-resource assessment can be found in [134].

- $\quad$ ERA5-Land: Covers the period from 1981 to two to three months ago, providing only a $9 \mathrm{~km}$ high resolution. Available data are hourly, daily, and monthly and can only be downloaded on a regular latitude/longitude grid of $0.1^{\circ} \times 0.1^{\circ}$ through the CDS catalog [135].

A recent European wind atlas, Energy System Potentials for Renewable Energy Sources (ENSPRESO) [136], is an open dataset based on MERRA reanalysis for energy models on renewable potentials, at regional and national levels for the 2010-2050 period. The European Meteorological High-Resolution Renewable Energy Source time series (EMHIRES) gives wind- and PV-power-generation time series for the EU-28, giving hourly time series and spanning 30 years (1986-2015) [137].

NOAA: Provides world wind climatology on a monthly basis from January 1979 to the current day [109], using NCEP-DOE Reanalysis 2 wind data. In addition, users can access weather stations included in the NOAA data [138] for hourly updated information. The goal is to provide data regarding both the variability and the trend of wind speed on a monthly basis and at a regional scale. A $10 \mathrm{~m}$ level was used for analysis purposes, and the resolution of the simulated data was approximately $1.9^{\circ} \times 1.9^{\circ}$. Monthly averaged wind speeds from the 1981-to-2020 base period were determined according to the daily average $\mathrm{U}$ (west-east) and V (south-north) wind components.

New European Wind Atlas: Uses a mesoscale and microscale model combining largescale atmospheric simulations (mesoscale) with topography models (microscale) [115]. From these models, the wind-resource potential was analyzed in large regions with high precision [139], reducing the time cost required to establish wind-power plant areas. The dataset has 30 years (1989-2018) of mesoscale simulations with the Weather, Research, and Forecasting (WRF) model at a $3 \mathrm{~km}^{2}$ resolution [140]. With regard to the data download options, only the mesoscale model data are able to be downloaded. The following heights are available:

- $\quad$ Mesoscale model: 50 m, 75 m, 100 m, and $150 \mathrm{~m}$.

- $\quad$ Microscale model: 50 m, 100 m, and $200 \mathrm{~m}$.

Apart from the wind speed and direction, other variables such as friction velocity, roughness, wind-power density, and air temperature can be downloaded as well (see Figure 4). 


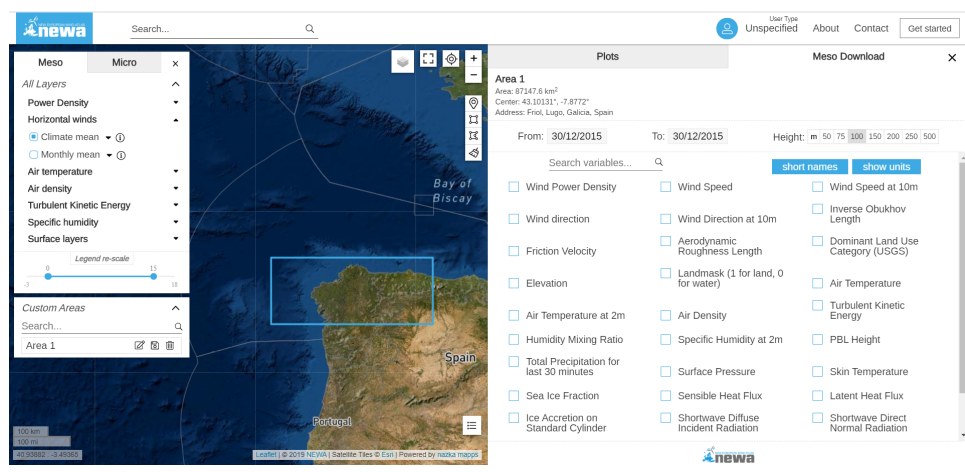

Figure 4. NEWA website. Data source: [115].

Vortex: Despite offering information under subscription, this database was included in this revision since it can be used in different applications, including graphic rendering, machine learning, and graph analytics [141]. Moreover, the data are highly useful for different companies due to the reliability and methodology used [116]. The Weather, Research, and Forecasting (WRF) model was implemented and developed with several atmospheric research centers. Additionally, 'Vortex EXTREMES' has been developed using the WRF-LES technology with 30 years of historical data. This technology analyzes extreme wind speeds and calculates the estimated wind speed in each 10-minute time interval (see Figure 5). A low-resolution mesoscale combined with historical data was used for simulation purposes, considering six extreme-wind-speed days per year. A 180-day time series was then selected for the whole 30-year period. The deliverables include wind-speed, wind-direction, and standard-deviation values. These variables were validated for heights between 50 and $300 \mathrm{~m}$. The information can be downloaded by considering coordinates or areas up to $400 \mathrm{~km}^{2}$.

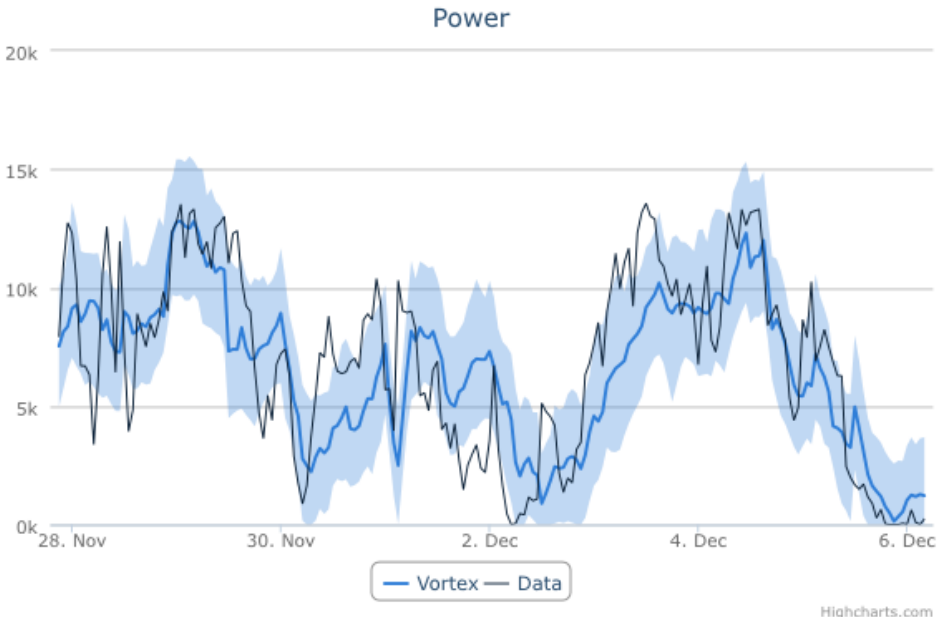

Figure 5. Wind-power simulation. Data source: [116].

Renewables Ninja: Simulates energy production per hour in wind-power plants based on coordinates. The main source data come from satellite observations, using NASA MERRA. Wind speeds are turned into power using the 'Virtual Wind Farm' (VWF) model [142]. The meteorological information includes data between a height of 10 and $150 \mathrm{~m}$. Registered users are able to access full information collected between 2000 and 2018. Anonymous users have access from 2014 to 2019 [117]. A simulation program, with a wind-turbine database, is also available for users. This software simulates the power generated by a turbine. Figure 6 shows the simulation of a $1 \mathrm{~kW}$ model turbine in 2019 . 


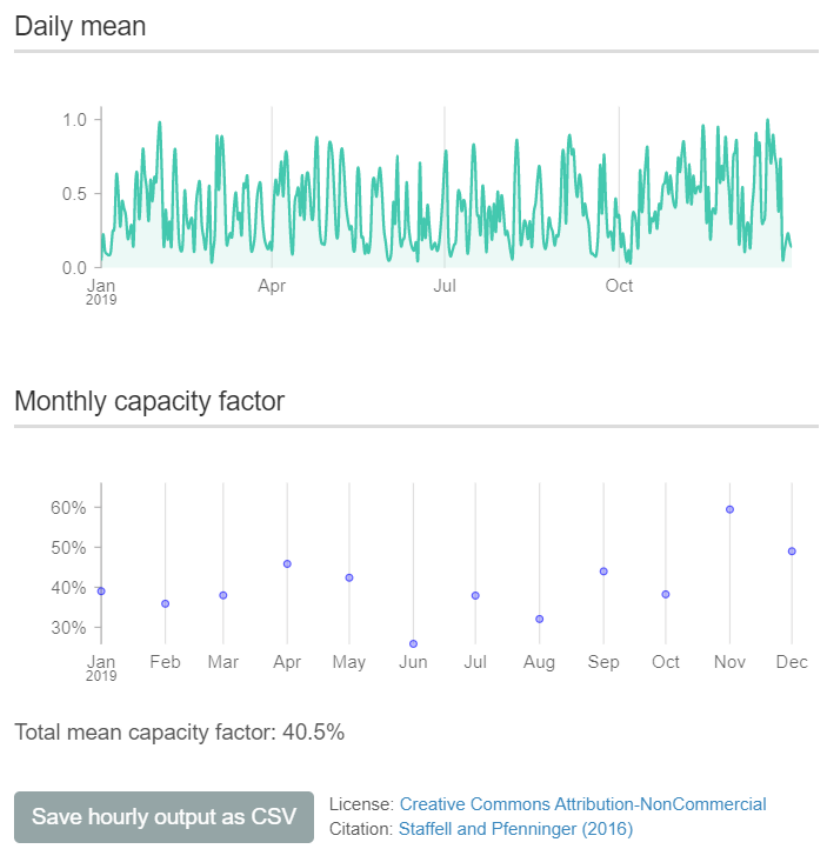

Figure 6. Simulation of power generation and capacity factor. Data source: [117].

WindFinder: Used for outdoor sports, such as surfing and fishing. A Globe Forecast System (GFS) is used in the forecasting process, which combines wind speed and direction forecast for 45,000 locations around the world. Real-time observations are available in 21,000 weather stations [118]. WindFinder shows the windiest areas at the same time, providing a general view of the meteorological situation everywhere. This fact contributes significantly to the decision-making tool, though measurements are not taken at the height of the wind-turbine nacelles. It can also forecast tides and waves that can be very helpful for offshore wind-farm platforms. GFS was developed by the National Centers for Environmental Prediction (NCEP) and is updated four times a day, with 16-day predictions. These predictions are not very reliable from the seventh day, and consequently, meteorological agencies use them until the 10th day.

Global Wind Atlas (GWA): The result of a partnership between the World Bank Group, funded by the Energy Sector Management Assistance Program (ESMAP) [143], and the Department of Wind Energy at the Technical University of Denmark (DTU, Wind Energy) [144]. All data provided by Global Wind Atlas [119] are validated and based on a wind-atlas methodology and the Wind Atlas Analysis and Application Program (WAsP). GWA uses a down-scaling process. Large-scale wind climate data are provided by atmospheric reanalysis, and $30 \mathrm{~km}$ data are input into a WRF mesoscale model using a $3 \mathrm{~km}$ spacing. These wind data are applied to a microscale model, made up of a WAsP based on estimations every $250 \mathrm{~m}$ at heights of 10,50, 100, 150, and $200 \mathrm{~m}$. Figure 7 shows the GWA down-scaling methodology [119]:

- $\quad$ Large-scale atmospheric data are used as input of the medium-scale mesoscale atmospheric models from re-analysis datasets.

- The output from the mesoscale modeling is generalized to be used as input for the microscale modeling.

- The output of the microscale modeling shows a high and relevant resolution topography with hills, summits, and forests.

Wind speed, wind direction, and roughness can be downloaded even $200 \mathrm{~km}$ away from the coastline. Their energy calculation tool estimates the annual energy production and capacity factor by using the wind-turbine power curve (see Figure 8) [119]. 


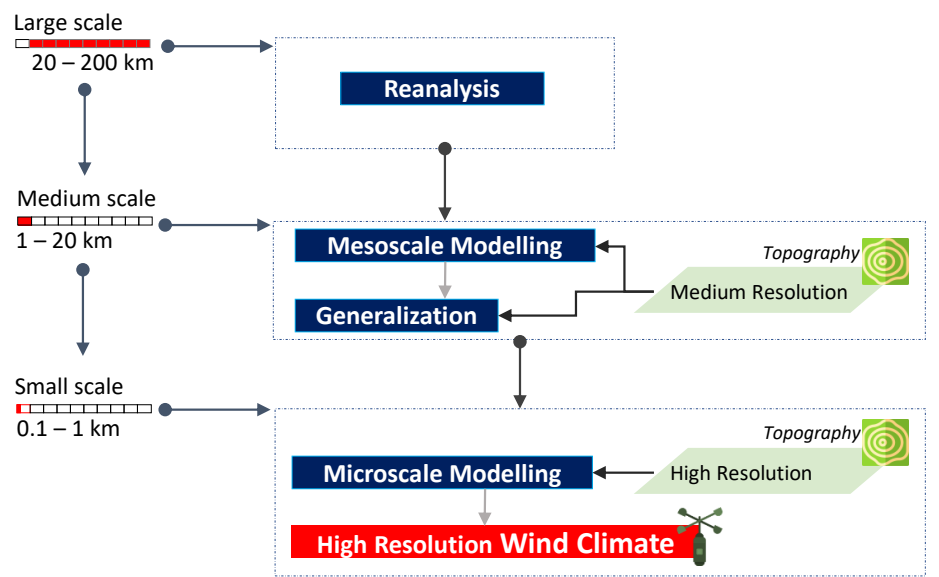

Figure 7. Downscale process. Own elaboration.

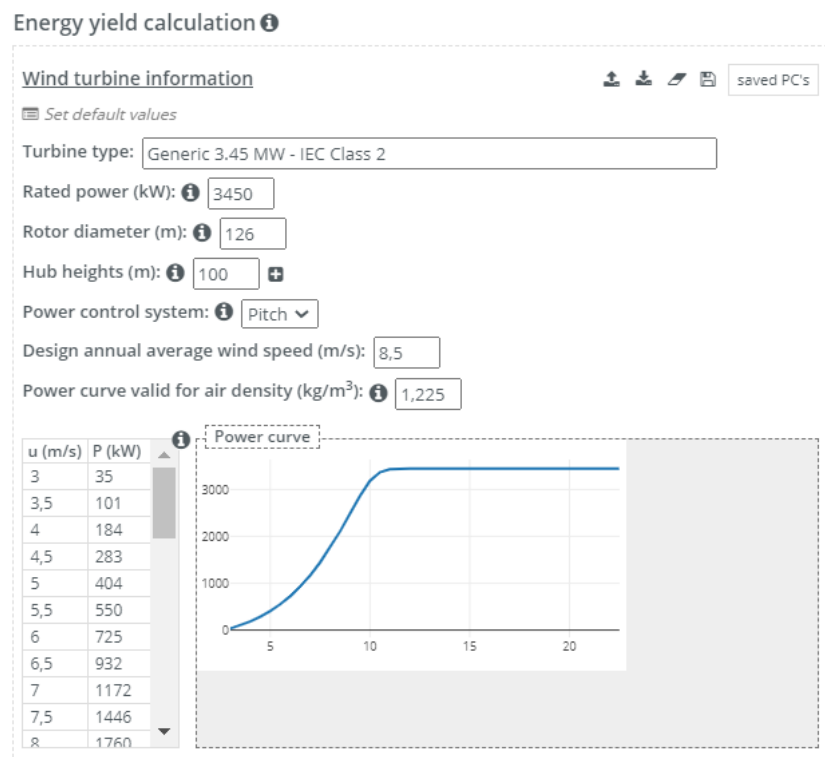

Figure 8. Energy estimation tool for a wind turbine. Data source: [119].

National Renewable Energy Laboratory (NREL): The National Renewable Energy Laboratory was funded by the U.S. Department of Energy. It is one of the major renewable energy laboratories across the world and includes instantaneous meteorological conditions and turbine-power calculations for more than 126,000 sites in the United States from 2007 to 2013 [124]. The meteorological data provide weather conditions in a $2 \mathrm{~km}^{2}$ grid cell. In addition, it includes parameters such as atmospheric stability, solar-radiation data, and wind profiles. Forecast data include a sample time of $1,4,6$, and $24 \mathrm{~h}$. The available heights for wind speed and direction are: (i) Onshore wind: 10, 40, 60, 80, 100, 120, 140, 160, and $200 \mathrm{~m}$; (ii) offshore wind: $90 \mathrm{~m}$.

$\mathrm{FiNO}_{3}$ Platform: The FINO company has three platforms located along the North and Baltic Sea. For this work, we only had access to the third platform $\left(\mathrm{FiNO}_{3}\right)$ built in 2009 (see Figure 9) [128]. It only provides information regarding such coasts, being an example to be followed by the rest of the information sources, as it provides sea-wind data in real time. $\mathrm{FiNO}_{3}$ is thus suitable for wind-energy research projects and offshore wind-site optimal locations. A relevant drawback of measuring meteorological variables at an offshore-specific site is meteorological mast maintenance, in comparison to an onshore site, including sensor and equipment maintenance over a long time period. Anemometers and other tools should be calibrated periodically, since their efficiency decreases drastically through time and sensor signal distortion [145]. $\mathrm{FiNO}_{3}$ 's available heights are: $34,42,51$, 
$62,71,82$, and $91 \mathrm{~m}$, including both direction and wind-speed data. Additional parameters are also collected, such as air pressure, air temperature, global radiation, rainfall, and UV radiation. All parameters are available and accessible from 2005 to the current day, with a 10-min sample time.

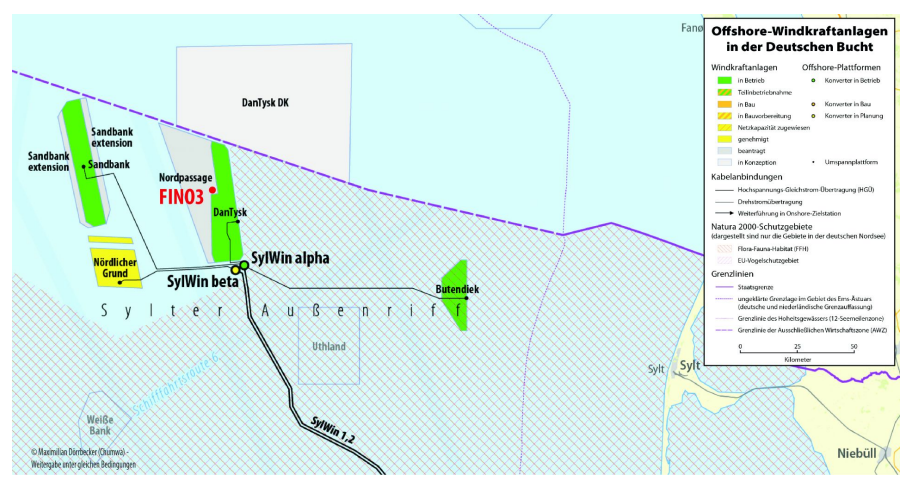

Figure 9. Location of $\mathrm{FiNO}_{3}$. Data source: [128].

NASA Power Larc: Provides solar and wind data using the Prediction Of Worldwide Energy Resources (POWER) project, in order to increase current renewable energy data, providing additional information from such satellite systems [130]. There are long-term weather estimations from satellites to supply reliable data, even in regions where weather stations are not available. Diary wind information is taken from 'Modern-Era Retrospective Analysis for Research and Applications' (MERRA-2), as was previously discussed, which provides updated information with a 25-min sample time approximately, pointing out maximum and minimum wind speeds in a certain position. A 22-year-old history for solar energy and more than 30 for wind data are also available for users. The Goddard Interactive Online Visualization and Analysis Infrastructure (Giovanni) has been used to conduct a variety of studies and explore data as well: environmental changes [146], dust [147,148], and aerosol analysis [149,150], etc. Wind-speed data are also available, but, according to the specific literature, they are mostly used for air-pollution analysis [151-154].

\subsection{Comparison of Wind Data Sources}

Table 3 shows the relevant wind information given by each web database analyzed in this work. Altitude information and sampling frequency about previous data are included and compared as well. Table 4 summarizes the methodology used to obtain the parameters, the minimum time frequency, the data source, and the cell grid size used for each database. The cell grid size represents the minimum downloadable area; the smaller the area, the better the measurement precision and accuracy.

As was expected, wind-speed module data are available to be downloaded in all data sources. In addition, $60 \%$ also provide the wind direction, $30 \%$ the wind power, and only one source (Global Wind Atlas) incorporates roughness data. The height of the data collection ranges between the surface measurements of buoys at sea level and a height of $200 \mathrm{~m}$. Nevertheless, some sources — such as Vortex-extrapolate the data to a height of more than $200 \mathrm{~m}$. The annual sampling campaign is ensured by $50 \%$ of the data sources, $40 \%$ monthly samplings, and $80 \%$ daily samplings with different hourly frequencies. Some sources participate in annual, monthly, and daily data campaigns, such as the Global Wind Atlas, Vortex, and ECMWF. With regard to the origin of the data, most of the database sources (90\%) are estimated from satellite data sources: $70 \%$ of the data are determined by simulations and/or predictions, and $20 \%$ of the data are directly provided by satellite sources. Consequently, only FINO uses terrestrial weather stations. The sample time of data collection ranges from $10 \mathrm{~min}$ to $3 \mathrm{~h}$. The cell area, related to the measurement accuracy, ranges from 9 to $40,000 \mathrm{~km}^{2}$. 
Table 3. Wind data analyzed, height, and sampling campaign. WS, wind speed; WD, wind direction; $\mathrm{WP}$, wind power.

\begin{tabular}{|c|c|c|c|}
\hline Source & Wind Data & Height (m) & Sampling Campaign \\
\hline ECMWF [99] & WS and WD & 10 and 30 & Annual, monthly, and daily \\
\hline NOAA [109] & WS & Superficial & Annual and monthly \\
\hline NEWA [115] & WS and WD & $\begin{array}{l}\text { Microscale: } 50,75,100,150 \\
\text { Mesoscale: } 50,100,200\end{array}$ & Daily (until 31 December 2018) \\
\hline Vortex [116] & WS, WD, and WP & Depends on coordinates & Annual, monthly, and daily \\
\hline Renewables.Ninja [117] & WS and WP & Between $10 \mathrm{~m}$ and $150 \mathrm{~m}$ & Hourly (until 31 December 2019) \\
\hline WindFinder [118] & WS and WD & Superficial & Forecast $(7-8 \mathrm{~h})$ frequency of $3 \mathrm{~h}$ \\
\hline Global Wind Atlas [119] & $\begin{array}{l}\text { Avg. WS, WD, and WP } \\
\text { Roughness }\end{array}$ & $10,50,100,150$, and 200 & Annual, monthly, and daily \\
\hline NREL [124] & WS & Onshore: 10-200, offshore: 90 & 2007-2013 \\
\hline $\mathrm{FiNO}_{3}[128]$ & WS and WD & Between 34 and 91 & Hourly, every $10 \mathrm{~min}$ \\
\hline NASA Power Larc [130] & WS (max. and min.) & 50 & Annual and daily (60 per day) \\
\hline
\end{tabular}

Table 4. Methodology, minimum downloading data frequency, source, and cell grid size. SB, satellitebased; GB, ground-based.

\begin{tabular}{|c|c|c|c|c|}
\hline Source & Methodology & Updating Data & Source & Cell Grid \\
\hline ECMWF [99] & Satellite simulation & - & SB & $10 \mathrm{~km}^{2}$ \\
\hline NOAA [109] & $\begin{array}{l}\text { Weather Station and } \\
\text { satellite simulation } \\
\text { (satellite measurements) }\end{array}$ & $1 \mathrm{~h}$ & SB & $40,000 \mathrm{~km}^{2}$ \\
\hline NEWA [115] & WRF (simulation) & - & SB & $\begin{array}{l}\text { Microscale: } 2500 \mathrm{~m}^{2} \\
\text { Mesoscale: } 9 \mathrm{~km}^{2}\end{array}$ \\
\hline Vortex [116] & $\begin{array}{l}\text { WRF } \\
\text { (prediction and simulation) }\end{array}$ & $10 \mathrm{~min}$ & SB & $30 \mathrm{~km}^{2}$ \\
\hline Renewables Ninja [117] & $\begin{array}{l}\text { MERRA } \\
\text { (satellite observations) }\end{array}$ & $1 \mathrm{~h}$ & SB & Only coordinates \\
\hline WindFinder [118] & $\begin{array}{l}\text { GFS } \\
\text { (forecast simulation) }\end{array}$ & $3 \mathrm{~h}$ & SB & - \\
\hline Global Wind Atlas [119] & WAsP (simulation) & $1 \mathrm{~h}$ & SB & $30 \mathrm{~km}^{2}$ \\
\hline NREL [124] & Satellite simulation & $1 \mathrm{~h}$ & SB & $30 \mathrm{~km}^{2}$ \\
\hline $\mathrm{FiNO}_{3}[128]$ & Wheather station & $10 \mathrm{~min}$ & GB & Only coordinates \\
\hline NASA Power Larc [130] & MERRA-2 & $25 \mathrm{~min}$ & SB & Every 2500 km² \\
\hline
\end{tabular}

\section{GIS Tool Integration}

In the field of energy analysis in general, and renewable energies in particular, the application of GIS has a long and productive trajectory [155]. Indeed, GIS tools have been widely used for large-scale techno-economic assessment of solar resources and powerpotential mapping [156], as well as wind-energy potential [157]. Under this framework, and by considering the contributions analyzed in this work, $83 \%$ of such contributions integrate GIS in their proposed methodologies (see Figure 10); $37 \%$ use data from national institutions of their specific case studies; and $40 \%$ use free-access sources of wind data available online. The GIS data source at a continental level and with free access that most researchers incorporate is ECMWF - $13 \%$ of the total. Table 5 shows a summary of the contributions ordered by GIS sources. Specific examples of the current GIS software packages often used in the renewable-energy source context are Quantum GIS (QGIS), ArcGIS, ILWIS, gvSIG, and Global Mapper [158], with ArcGIS being the most common software and QGIS being used much less frequently. The QGIS tool is a free GIS software to be used to represent vector files and raster data. The data format from each website can be subsequently analyzed and compared in order to achieve the best solution for wind-site 
location projects. This tool allows us to combine different parameters from several sources, providing relevant advantages for wind calculation and decision-making processes.

Table 5. Results of the identification by contributions with GIS tool integration.

\begin{tabular}{|c|c|c|c|}
\hline \multirow[b]{2}{*}{ GIS Resource } & \multicolumn{3}{|c|}{ References by Objective } \\
\hline & Optimization & Forecasting & Potential \\
\hline Institutions of the country & {$[17,25,29,48-54,58-61,93,159]$} & {$[64,67-71,97,111]$} & {$[60,73-76,85,92]$} \\
\hline Other studies & {$[64,78,80,83,94]$} & 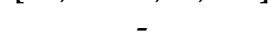 & [160-162] \\
\hline Databases without free access & {$[33,62,86]$} & - & - \\
\hline Unidentified & - & [105] & - \\
\hline Technical reports & - & [91] & - \\
\hline Simulations & {$[28,92,95]$} & {$[90]$} & {$[110,163]$} \\
\hline ECMWF [99] & {$[31,101,102]$} & {$[66,84,103,104]$} & [102,106-108] \\
\hline NOAA [109] & [110] & {$[65,112-114]$} & - \\
\hline NEWA [115] & - & - & - \\
\hline Renewables.Ninja [117] & - & - & - \\
\hline Global Wind Atlas [119] & {$[85,120]$} & {$[72,121,122]$} & {$[98,123]$} \\
\hline NREL [124] & {$[125]$} & [126] & {$[27,127]$} \\
\hline FINO [128] & - & - & - \\
\hline NASA Power Larc [130] & - & [66] & {$[107,108,123,131-133]$} \\
\hline
\end{tabular}

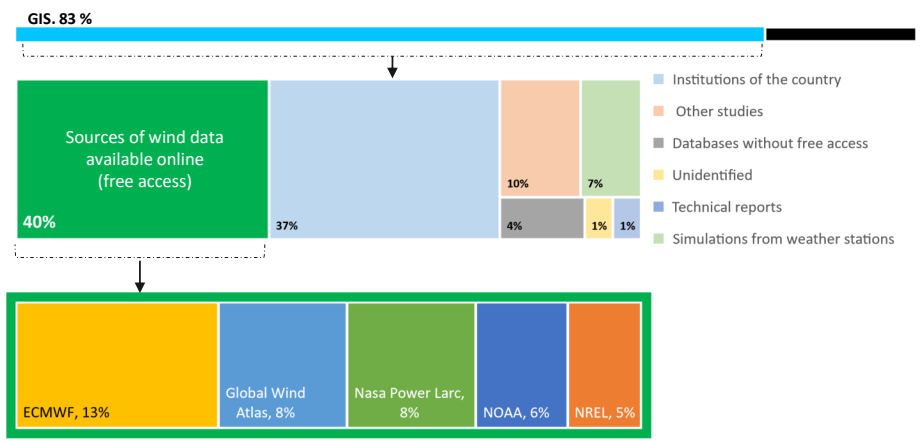

Figure 10. Results of identification by contributions. GIS integration. Own elaboration.

The characterization of wind data sources with GIS tool integration by each webdatabase summarized in Table 3 are discussed as follows:

ECMWF: Wind speed (in m/s) can be downloaded, for a height of $10 \mathrm{~m}$, in ucomponent (speed from west (-) to east (+)) and $v$-component (speed from south (-) to north $(+))$. The downloaded information is available worldwide. In Figure 11, the wind speed in the $v$-component is represented by the QGIS tool. The negative wind speed v-component is represented by the QGIS tool. The negative wind speed v-component represents the south direction, and the positive wind speed represents the north direction.

NOAA: The parameters are available worldwide, as NOAA has access to weather stations around the world [138]. The sky cover, sea level pressure, temperature, dew point, etc. are available to be downloaded, but only wind speed/direction data are used by considering our proposals. The information cannot be represented in QGIS, since the downloaded format is . csv. However, wind speed is classified by direction, suitable for determining the compass rose and the wind frequencies in a specific area-at the weatherstation height. As an example, Figure 12 shows the classified wind speed for the A Coruna 08002099999 meteorological station, located at A Coruña airport (Spain), at a height of $98.45 \mathrm{~m}$.

New European Wind Atlas: This website offers a large variety of wind-data parameters, all of which can be represented in GIS tools, since they are raster layers of data, being helpful for these programs. Offshore wind-application data were downloaded for our 
analysis purpose, despite additional information also being available, such as the windpower density, wind speed, wind direction, and air temperature. With this aim, we selected such wind data at $75 \mathrm{~m}$ [115]. As an example, Figure 13 shows how a layer is generated using data downloaded in QGIS, based on the range of values for each parameter and depending on each coordinate. The wind energy generated according to the wind turbine location can also be represented (see Figure 14).

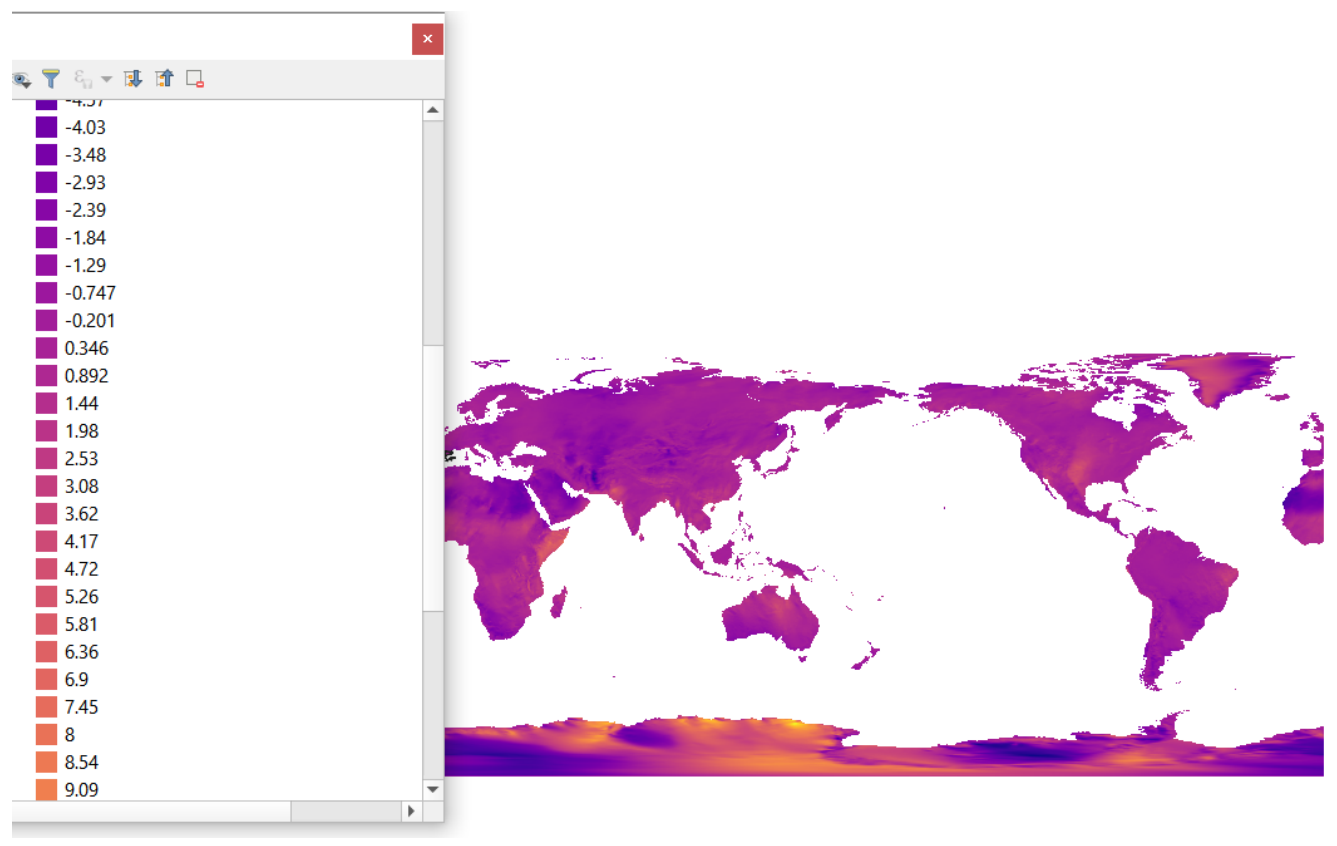

Figure 11. ECMWF: Wind speed $(\mathrm{m} / \mathrm{s})$ at $10 \mathrm{~m} v$-component of wind. Own elaboration.
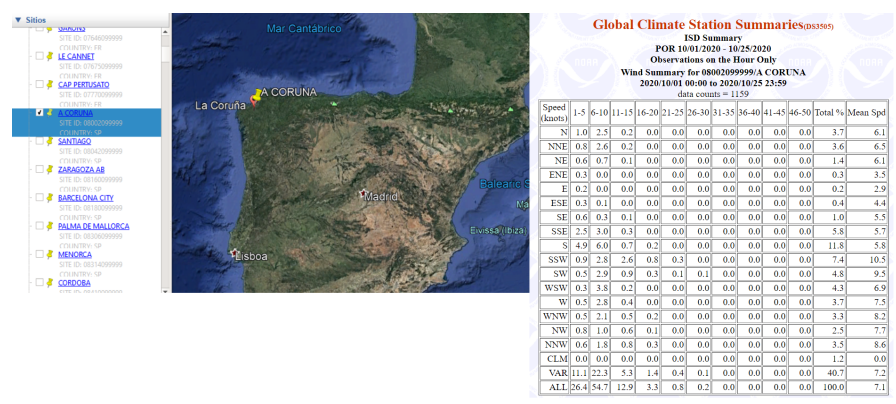

Figure 12. NOAA: Classified wind speed (A Coruña (Spain) airport). Own elaboration.

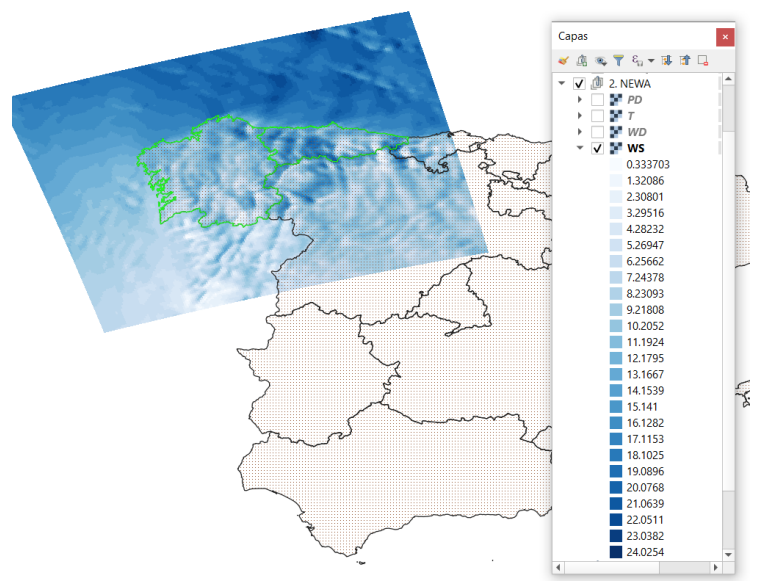

Figure 13. NEWA: Wind speed $(\mathrm{m} / \mathrm{s})$ at $75 \mathrm{~m}$. Own elaboration. 


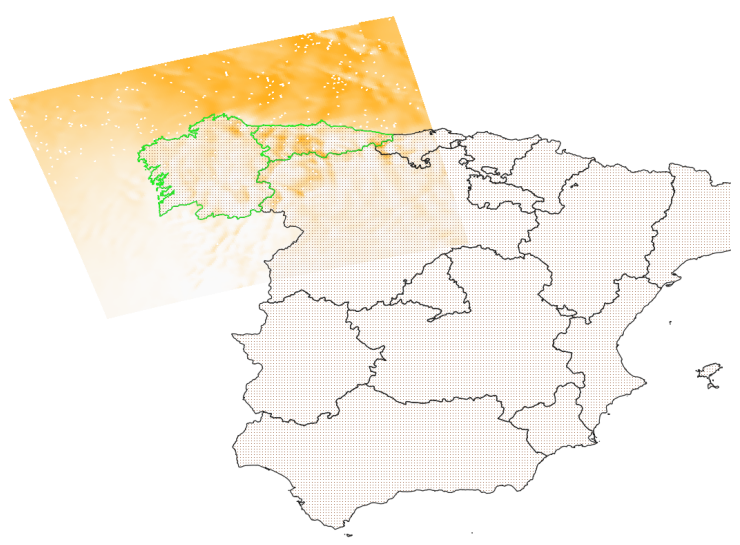

Figure 14. NEWA: Wind power $\left(\mathrm{W} / \mathrm{m}^{2}\right)$ at $75 \mathrm{~m}$. Own elaboration.

Vortex: Requires a paid subscription to download any type of information. Subsequently, it is not possible to represent any type of wind data in QGIS [116].

Renewables Ninja: Apart from downloading wind-speed information, Renewables.ninja calculates the power generation to be provided by a certain turbine [117]. It has a wide range of turbines from various companies such as Enercon, Gamesa, General Electric, Siemens, and Vestas. Data are downloaded in .csv format, available for integration with QGIS. However, wind speed cannot be represented in QGIS, as it is downloaded for a specific location through coordinates. It could be useful within other influence factors from the area, such as a Special Protection Area for Birds (SPAB) or areas of marine traffic, allowing to determine the most suitable area for wind-site locations.

WindFinder: WindFinder also requires a subscription to download wind information [118]. The main objective of this study was the analysis and comparison of open-access information resources, and, thus, QGIS compatibility is not possible with this website.

Global Wind Atlas: The methodology used by the Global Wind Atlas provides interesting parameters on weather; however, the only parameter compatible with GIS tools is wind speed. Data are downloaded using coordinates or drawing a rectangle on the map, covering a certain area or even a country [119]. Figure 15 shows an example of downloaded data for two Spanish regions (Galicia and Asturias), covering an area of approximately $15,000 \mathrm{~km}^{2}$. The raster layer format can be downloaded as well. Classifying the parameters by their values, a $100 \mathrm{~m}$ height wind speed in Galicia and Asturias Spanish regions can be represented in QGIS (see Figure 16).

NREL: This website only has data from U.S. open-access information about the windspeed module, and the direction at a $90 \mathrm{~m}$ height is available for offshore parameters (see Figure 17) or between a height of 10 and $200 \mathrm{~m}$ for onshore wind-power plants [124]. Data can be downloaded in .csv format or as a .shp layer file. In this way, the .csv files can be used for mathematical purposes and . shp files to represent maps in QGIS tool. Figure 18 represents graphics in QGIS, showing the wind speed in $0.5 \mathrm{~m} / \mathrm{s}$ ranges.

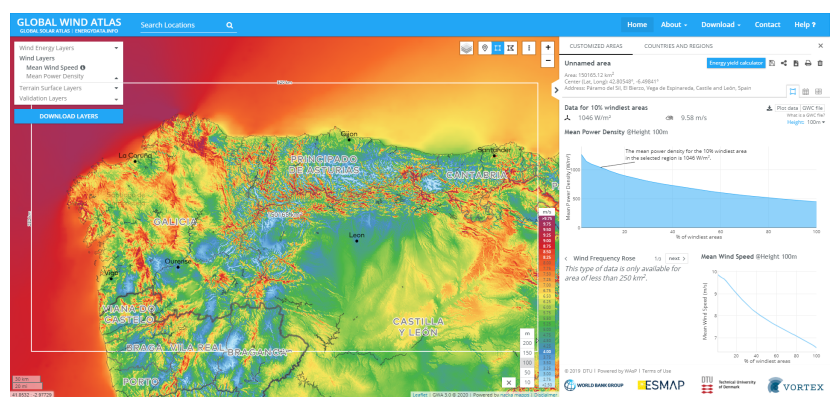

Figure 15. Global Wind Atlas: Download data for a height of $100 \mathrm{~m}$, drawing a rectangle. Data source: [119]. 


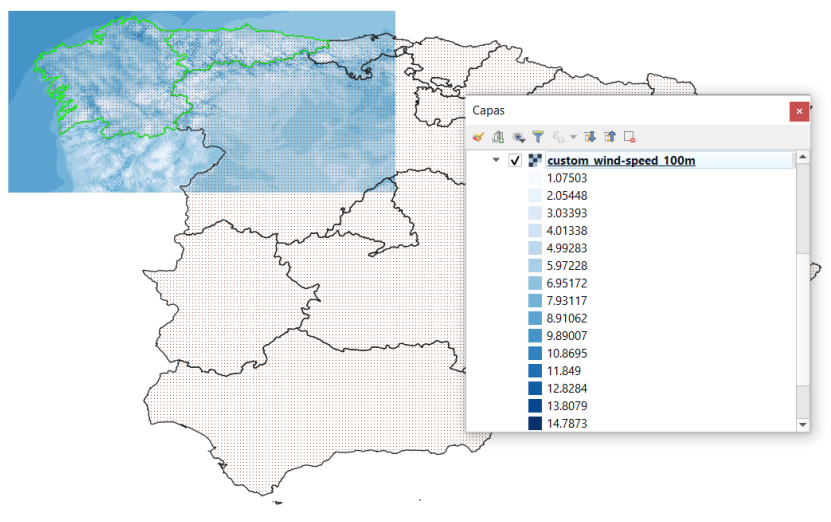

Figure 16. Global Wind Atlas: Wind speed (m/s) at $100 \mathrm{~m}$. Own elaboration.

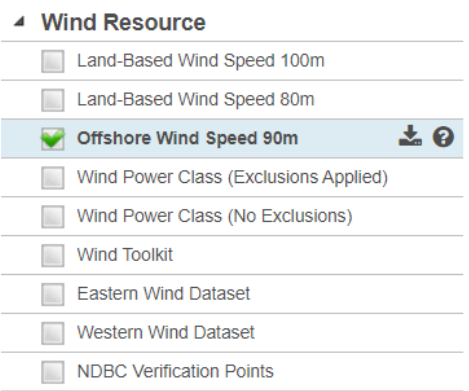

Figure 17. NREL: Available wind parameters. Data source: [124].

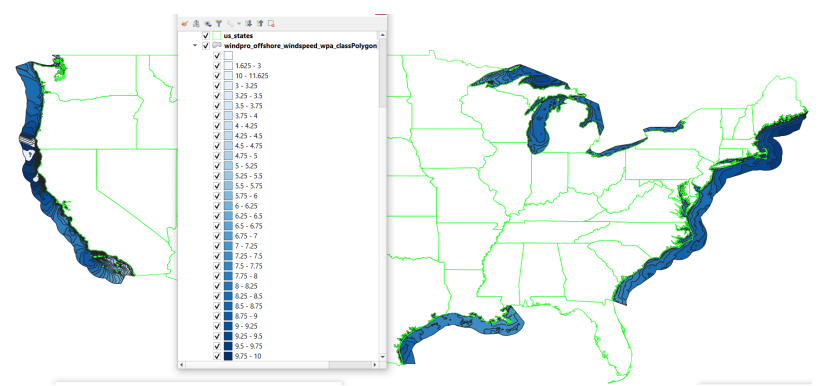

Figure 18. NREL: Wind speed (m/s) in QGIS. Own elaboration.

$\mathrm{FiNO}_{3}$ Platform: This platform works for the North and Baltic Sea. Wind speed and direction are measured between a height of 34 and $91 \mathrm{~m}$, due to the measurement system's location along the entire platform [128]. The parameters are downloaded in .dat format, needing to be converted into .csv files to be used in QGIS (Figure 19). As Renewables.ninja information, it is not easy to represent the obtained results in GIS, since they are limited in terms of being downloaded for a specific location.

NASA Power Larc: Data from the northwest coast of Spain can be downloaded. Large land simulations are limited, due to the fact that the NASA website allows to download data through defining specific coordinates. A $50 \mathrm{~m}$ height wind speed can be downloaded and plotted via QGIS, since NASA data are available in .csv format. Figure 20 represents the previous point in QGIS and all downloaded information as . csv file. It contains $50 \mathrm{~m}$ height-averaged wind speeds. 


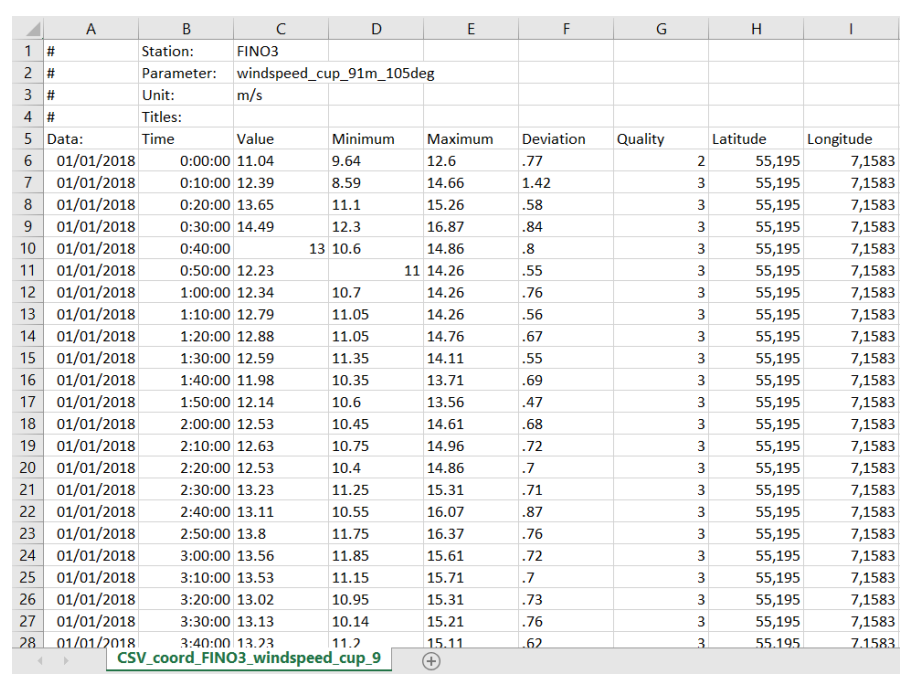

Figure 19. $\mathrm{FiNO}_{3}$ : Downloaded parameters in .csv format. Data source: [128].

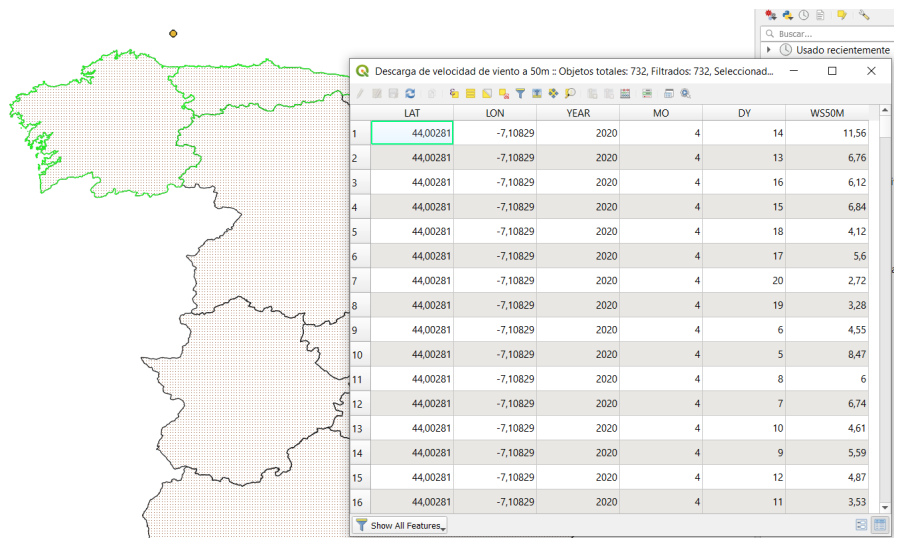

Figure 20. NASA Power Larc: Wind speed (m/s) at $50 \mathrm{~m}$. Data source [130].

As a summary, the analyzed database resources allowed us to download extensive information compatible with GIS tools. Some parameters can be represented in QGIS, while others parameters only provide wind information for specific coordinates, addressing additional difficulties to represent such data. GIS tool integration is useful since it combines different parameters in a more convenient manner. These parameters can influence windsite development, such as terrain, altitude, wind speed and direction, and temperatures. The possibility of combining a wide range of sources considerably simplifies the process. Some factors, such as sea floor depth and wind speed and direction, can be decisive in the selection of wind turbine locations. Therefore, compatibility with GIS tools is needed and, moreover, should be required for future wind-site-location and evaluation projects. Table 6 shows the integration methodology of each analyzed source in QGIS, as well as all of the downloadable file formats for each of them. Eighty percent of the data sources can be integrated with GIS with open access, five of them spatially through thematic layers and three of them with open . csv formats. 
Table 6. GIS tool integration and downloadable format.

\begin{tabular}{lllll}
\hline Source & GIS Integration & Download Format & Sample Time & Download Limit \\
\hline NOAA [109] & Coordinate data & .csv & - & - \\
NEWA [115] & Color mapping & Shape (.nc) & $30 \mathrm{~min}$ & Hourly, day by day \\
Vortex [116] & - & - & - & - \\
Renewables Ninja [117] & Coordinate data & .csv & $1 \mathrm{~h}$ & Hourly, year by year \\
WindFinder [118] & - & - & - & - \\
Global Wind Atlas [119] & Color mapping & Shape (.tiff) & - & - \\
NREL [124] & Color mapping & Shape (.shp)y .csv & - & - \\
FiNO 3 [128] & Coordinate data & .csv & $10 \mathrm{~min}$ & Hourly, year by year \\
NASA Power Larc [130] & Coordinate data & .csv & Daily & Daily, year by year \\
\hline
\end{tabular}

\section{Discussion}

With the aim of comparing simulated/estimated data to real data, all downloaded data were located at a specific point, where real measurements were also available. The chosen location was the $\mathrm{FiNO}_{3}$ offshore wind platform in the North Sea (coordinates: 55.194981 $\left.7.158293^{\circ}\right)$. A comparison of the wind-speed-module and the direction data was first carried out, including the rest of the parameters that influence wind characteristics, i.e., the wind speed and the wind orientation, for a height of approximately $100 \mathrm{~m}$. However, in order to compare $\mathrm{FiNO}_{3}$ to NASA Power Larc, the height was $50 \mathrm{~m}$, since it was the maximum height available to be downloaded from the NASA website, and $\mathrm{FiNO}_{3}$ provides wind-speed measurements from 31 to $91 \mathrm{~m}$.

Among the analyzed database resources, only four website sources were able to be compared: $\mathrm{FiNO}_{3}$, Renewables.ninja, NEWA, and Nasa Power Larc. The values provided by the rest of the sources did not allow us to compare them to $\mathrm{FiNO}_{3}$, due to different circumstances, such as the format of representation of their values, the available locations, or the wind-speed-measurement height. The time periods for data-comparison purposes were years, months, and days. This proposed analysis thus compared the variations and errors among the resources, based on the measured $\mathrm{FiNO}_{3}$ information and the rest of the resources previously described and discussed in Section 4.1. Figure 21 represents the most accurate comparison based on hourly measurements. As can be seen, in general, the downloaded data were similar to the $\mathrm{FiNO}_{3}$ data-the deviation was between $2 \%$ and $3 \%$ of the $\mathrm{FiNO}_{3}$ database. Figure 22 shows the daily average for January between $\mathrm{FiNO}_{3}$ and Renewables.ninja, with their deviation being around $10.51 \%$. This difference can be better appreciated because the measurements are more accurate than an annual comparison. The yearly comparison shows 365 measures of the average of the hourly wind data source (see Figure 23). This fact makes the measurements look real in graphical representation, but there are large differences between the sources ( $29 \%$ between $\mathrm{FiNO}_{3}$ and Nasa Power Larc, extrapolated to a $100 \mathrm{~m}$ height). Table 7 shows a summary of the different sources studied and the variation with respect to the real measurement $\left(\mathrm{FiNO}_{3}\right)$. As can be seen, the higher the comparison interval, the higher the percentage of error committed. This fact is due to the different sample time used for the data measurements and estimations: Simulations were hourly estimated, and averages of such hourly data were then used to obtain the corresponding monthly and annual yields.

Table 7. Deviation compared to the $\mathrm{FiNO}_{3}$ database.

\begin{tabular}{lccc}
\hline Source & Daily & Monthly & Yearly \\
\hline NEWA [115] & $2.46 \%$ & & \\
Renewables Ninja [117] & $2.78 \%$ & $10.51 \%$ & $11.60 \%$ \\
Nasa Power Larc [130] & & & $29.05 \%$ \\
\hline
\end{tabular}




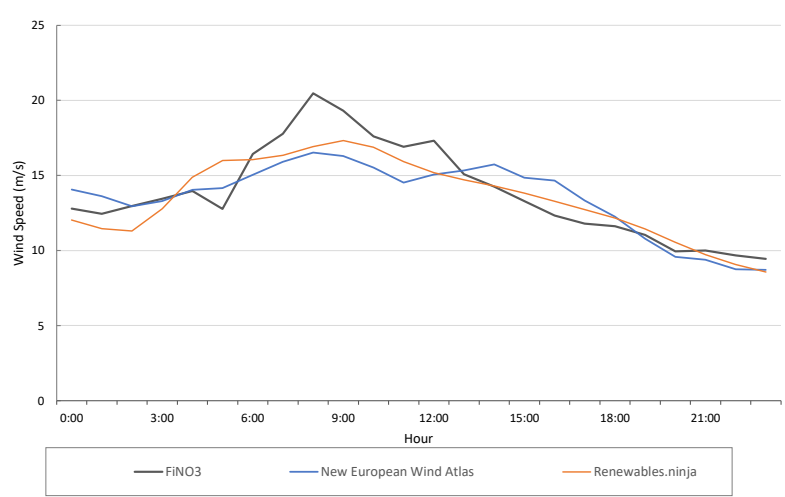

Figure 21. Hourly comparison (1 January 2018). Own elaboration.

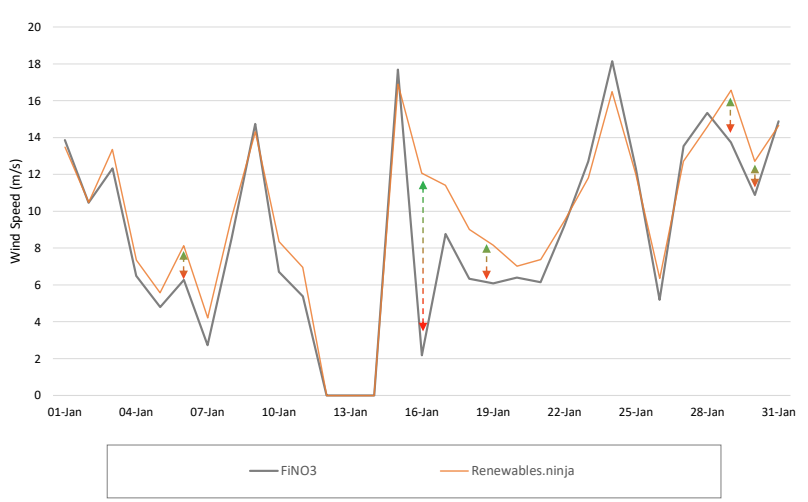

Figure 22. Monthly comparison (January 2018). Own elaboration.

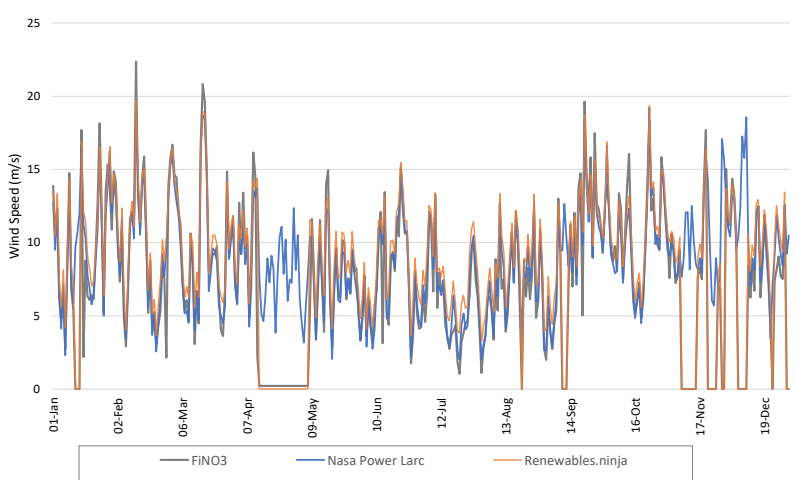

Figure 23. Yearly comparison (2018). Own elaboration.

In general, all of the analyzed data resources provide extensive wind information, and most of them can be integrated into GIS tools. However, not all of them allowed us to download information in compatible formats for these purposes, as graphical representations would simplify the analysis. Table 8 shows a summary of the main improvements available to be implemented, aiming to improve the databases according to each of the data sources previously analyzed. In this table, HT represents an increase height to $100 \mathrm{~m}$ to match the measurement scale of each source; CSV is the download database in . csv format to process the data in editable format; GIS is the integration in GIS tools and the possibility to graphically represent the downloaded data; INT is the international information available to compare sources at any location; and RT is the real-time measurements for a more-accurate calculation. 
Table 8. Summary of the main improvements available to be implemented.

\begin{tabular}{lccccc}
\hline Source & HT & CSV & GIS & INT & RT \\
\hline ECMWF & $X$ & $X$ & & & $X$ \\
NOAA & $X$ & $X$ & & $X$ \\
NEWA & & $X$ & $X$ & & $X$ \\
Vortex & & & & $X$ \\
Renewables.Ninja & $X$ & $X$ & & $X$ \\
WindFinder & & $X$ & $X$ & $X$ \\
Global Wind Atlas & & & $X$ & $X$ \\
NREL & $X$ & & & \\
FINO & & & & \\
NASA Power Larc & $X$ & & & \\
\hline
\end{tabular}

\section{Conclusions}

Renewable energy sources are increasingly integrated into the energy sector. One of the main resources and most mature technologies of renewables is wind energy. Nevertheless, it is necessary to obtain more and more wind information to optimize wind-energy locations and projects in a more-efficient manner. The wind-speed module and the direction are the main parameters to be considered under the process of designing a wind-power plant. With this aim, an analysis and comparison of open-access wind database sources at the same location was proposed and discussed herein. The location chosen was the $\mathrm{FiNO}_{3}$ platform. The proposed methodology included a direct identification of open-access wind databases through their corresponding websites and via an indirect process through the revision of contributions in the specific literature related to the optimal selection of wind sites and their possible integration with GIS tools. From this previous study, 32 data sources with meteorological variables were initially identified, as well as 375 potential contributions in the specific literature. A final group of 10 databases was selected for this analysis; all of them included data on the wind-speed module, $60 \%$ on wind direction, and only one on roughness. The height of the data collection ranged between the surface measurements of buoys at sea level and $200 \mathrm{~m}$. The annual sampling campaign was ensured by $50 \%$ of the data sources, $40 \%$ of monthly samplings, and $80 \%$ of daily samplings with different hourly frequencies. Ninety percent of the data had their origins in satellite data sources. The frequency of data collection ranged from $10 \mathrm{~min}$ to $3 \mathrm{~h}$. Comparing sources from which data could be downloaded in .csv format, there were deviations of the simulated data from $2-3 \%$ to $11 \%$ with respect to real measurements from the $\mathrm{FiNO}_{3}$ platform. These differences may be acceptable, because they depend on the simulated time interval.

Compatibility with GIS tools was also considered, since these tools are able to combine different wind resources. In addition, this additional GIS compatibility facilitates the windturbine location and selection. According to the online database resources, there was a wide range of wind parameters initially available, but those compatible with GIS tool facilitate calculations. From the selected wind-atlas databases, $80 \%$ of such data sources were able to be integrated with GIS into open-access databases, five of them spatially through thematic layers, and three of them with an open .csv format. A discussion of the main improvements available to be implemented on each wind atlas was also included in this work. This wind-atlas-database analysis is very useful for future research related to wind energy. Especially for wind-resource evaluation and wind-site location, reducing barriers to accessing wind data and facilitating their integration with other tools is important.

Author Contributions: Conceptualization, A.S.-d.R. and M.S.G.-C.; methodology, I.C.G.-G.; software, A.S.-d.R. and Á.M.-G.; formal analysis, A.S.-d.R. and I.C.G.-G.; resources, Á.M.-G.; data curation, A.S.-d.R.; writing — original draft preparation, M.S.G.-C. and Á.M.-G.; writing—review and editing, Á.M.-G.; supervision, M.S.G.-C. and Á.M.-G. All authors have read and agreed to the published version of the manuscript. 
Funding: This work was partially supported by the Ministry of Science and Innovation, Spain, (MEREA-TEA 0117125107-125107-4-21).

Institutional Review Board Statement: Not applicable.

Informed Consent Statement: Not applicable.

Data Availability Statement: The data that support the findings of this study are available from the corresponding author, Á.M.-G., upon reasonable request.

Acknowledgments: Data was made available by the FINO (Forschungsplattformen in Nord- und Ostsee) initiative, which was funded by the German Federal Ministry of Economic Affairs and Energy (BMWi) on the basis of a decision by the German Bundestag, organized by the Projekttraeger Juelich (PTJ) and coordinated by the German Federal Maritime and Hydrographic Agency (BSH).

Conflicts of Interest: The authors declare no conflict of interest.

$\begin{array}{ll}\text { Abbreviations } \\ \text { The following abbreviations are used in this manuscript: } \\ \text { ECMWF } & \text { European Centre for Medium-Range Weather Forecasts } \\ \text { EMHIRES } & \text { European Meteorological High-Resolution Renewable Energy Source } \\ \text { ENSPRESO } & \text { Energy System Potentials for Renewable Energy Sources } \\ \text { ESMAP } & \text { Energy Sector Management Assistance Program } \\ \text { GFS } & \text { Globe Forecast System } \\ \text { GIS } & \text { Geographic Information System } \\ \text { GWA } & \text { Global Wind Atlas } \\ \text { MERRA } & \text { Modern-Era Retrospective Analysis for Research and Applications } \\ \text { NASA } & \text { National Aeronautics and Space Administration } \\ \text { NCEP } & \text { National Centers for Environmental Prediction } \\ \text { NEWA } & \text { New European Wind Atlas } \\ \text { NOAA } & \text { Global Marine Data Map } \\ \text { NREL } & \text { National Renewable Energy Laboratory } \\ \text { POWER } & \text { Prediction Of Worldwide Energy Resources } \\ \text { PRISMA } & \text { Preferred Reporting Items for Systematic Reviews and Meta-Analyses } \\ \text { SPAB } & \text { Special Protection Area for Birds } \\ \text { U.S. } & \text { United States } \\ \text { WAsP } & \text { Wind Atlas Analysis and Application Program } \\ \text { WMO } & \text { World Meteorological Organization } \\ \text { WRF } & \text { Weather, Research, and Forecasting } \\ \text { VWF } & \text { Virtual Wind Farm }\end{array}$

\section{References}

1. Derlukiewicz, N.; Mempel-Śnieżyk, A.; Mankowska, D.; Dyjakon, A.; Minta, S.; Pilawka, T. How do Clusters Foster Sustainable Development? An Analysis of EU Policies. Sustainability 2020, 12, 1297 . [CrossRef]

2. Arroyo M., F.R.; Miguel, L.J. Low-Carbon Energy Governance: Scenarios to Accelerate the Change in the Energy Matrix in Ecuador. Energies 2020, 13, 4731. [CrossRef]

3. Renn, O.; Marshall, J.P. Coal, nuclear and renewable energy policies in Germany: From the 1950s to the "Energiewende". Energy Policy 2016, 99, 224-232. [CrossRef]

4. Cihat Onat, N.; Aboushaqrah, N.N.; Kucukvar, M.; Tarlochan, F.; Magid Hamouda, A. From sustainability assessment to sustainability management for policy development: The case for electric vehicles. Energy Convers. Manag. 2020, 216 , 112937. [CrossRef]

5. Agyeman, J.K.; Ameyaw, B.; Li, Y.; Appiah-Kubi, J.; Annan, A.; Oppong, A.; Twumasi, M.A. Modeling the long-run drivers of total renewable energy consumption: Evidence from top five heavily polluted countries. J. Clean. Prod. 2020, $277,123292$. [CrossRef]

6. Lamperti, F.; Dosi, G.; Napoletano, M.; Roventini, A.; Sapio, A. Climate change and green transitions in an agent-based integrated assessment model. Technol. Forecast. Soc. Chang. 2020, 153, 119806. [CrossRef]

7. Möller, B.; Hong, L.; Lonsing, R.; Hvelplund, F. Evaluation of offshore wind resources by scale of development. Energy 2012, 48,314-322. 6th Dubrovnik Conference on Sustainable Development of Energy Water and Environmental Systems, SDEWES 2011. [CrossRef] 
8. Zhang, Y.; Ai, Q.; Xiao, F.; Hao, R.; Lu, T. Typical wind power scenario generation for multiple wind farms using conditional improved Wasserstein generative adversarial network. Int. J. Electr. Power Energy Syst. 2020, 114, 105388. [CrossRef]

9. Fernández-Guillamón, A.; Das, K.; Cutululis, N.; Molina-García, A. Offshore Wind Power Integration into Future Power Systems: Overview and Trends. J. Mar. Sci. Eng. 2019, 7, 399. [CrossRef]

10. Global Wind Energy Council (GWEC). Global Wind Report 2020; Technical Report; GWEC: Brussels, Belgium, 2021.

11. Gil-García, I.C.; García-Cascales, M.S.; Fernández-Guillamón, A.; Molina-García, A. Categorization and Analysis of Relevant Factors for Optimal Locations in Onshore and Offshore Wind Power Plants: A Taxonomic Review. J. Mar. Sci. Eng. $2019,7,391$. [CrossRef]

12. Nedaei, M.; Assareh, E.; Biglari, M. An extensive evaluation of wind resource using new methods and strategies for development and utilizing wind power in Mah-shahr station in Iran. Energy Convers. Manag. 2014, 81, 475-503. [CrossRef]

13. Barbosa de Alencar, D.; De Mattos Affonso, C.; Limão de Oliveira, R.C.; Moya Rodríguez, J.L.; Leite, J.C.; Reston Filho, J.C Different Models for Forecasting Wind Power Generation: Case Study. Energies 2017, 10, 1976. [CrossRef]

14. Demolli, H.; Dokuz, A.S.; Ecemis, A.; Gokcek, M. Wind power forecasting based on daily wind speed data using machine learning algorithms. Energy Convers. Manag. 2019, 198, 111823. [CrossRef]

15. Yang, W.; Wang, J.; Lu, H.; Niu, T.; Du, P. Hybrid wind energy forecasting and analysis system based on divide and conquer scheme: A case study in China. J. Clean. Prod. 2019, 222, 942-959. [CrossRef]

16. Zhang, L.; Dong, Y.; Wang, J. Wind Speed Forecasting Using a Two-Stage Forecasting System With an Error Correcting and Nonlinear Ensemble Strategy. IEEE Access 2019, 7, 176000-176023. [CrossRef]

17. Kim, C.K.; Jang, S.; Kim, T.Y. Site selection for offshore wind farms in the southwest coast of South Korea. Renew. Energy 2018, 120, 151-162. [CrossRef]

18. Fazelpour, F.; Tarashkar, N.; Rosen, M.A. Short-term wind speed forecasting using artificial neural networks for Tehran, Iran. Int J. Energy Environ. Eng. 2016, 7, 377-390. [CrossRef]

19. Rezaeiha, A.; Montazeri, H.; Blocken, B. A framework for preliminary large-scale urban wind energy potential assessment: Roof-mounted wind turbines. Energy Convers. Manag. 2020, 214, 112770. [CrossRef]

20. El Khchine, Y.; Sriti, M.; El Kadri Elyamani, N.E. Evaluation of wind energy potential and trends in Morocco. Heliyon 2019, 5, e01830. [CrossRef]

21. Bahrami, A.; Teimourian, A.; Okoye, C.O.; Shiri, H. Technical and economic analysis of wind energy potential in Uzbekistan. $J$. Clean. Prod. 2019, 223, 801-814. [CrossRef]

22. Talama, F.; Kutty, S.S.; Kumar, A.; Khan, M.; Ahmed, M.R. Assessment of wind energy potential for Tuvalu with accurate estimation of Weibull parameters. Energy Explor. Exploit. 2020, 38, 1742-1773. [CrossRef]

23. Sumair, M.; Aized, T.; Gardezi, S.A.R.; Rehman, S.U.U.; Rehman, S.M.S. Wind potential estimation and proposed energy production in Southern Punjab using Weibull probability density function and surface measured data. Energy Explor. Exploit. 2020, 39, 2150-2168. [CrossRef]

24. Vargas, S.A.; Esteves, G.R.T.; Maçaira, P.M.; Bastos, B.Q.; Cyrino Oliveira, F.L.; Souza, R.C. Wind power generation: A review and a research agenda. J. Clean. Prod. 2019, 218, 850-870. [CrossRef]

25. Ali, S.; Taweekun, J.; Techato, K.; Waewsak, J.; Gyawali, S. GIS based site suitability assessment for wind and solar farms in Songkhla, Thailand. Renew. Energy 2018, 132, 1360-1372. [CrossRef]

26. Aydin, N.Y.; Kentel, E.; Duzgun, S. GIS-based environmental assessment of wind energy systems for spatial planning: A case study from Western Turkey. Renew. Sustain. Energy Rev. 2010, 14, 364-373. [CrossRef]

27. Ayodele, T.; Ogunjuyigbe, A.; Odigie, O.; Munda, J. A multi-criteria GIS based model for wind farm site selection using interval type-2 fuzzy analytic hierarchy process: The case study of Nigeria. Appl. Energy 2018, 228, 1853-1869. [CrossRef]

28. Baseer, M.; Rehman, S.; Meyer, J.; Alam, M.M. GIS-based site suitability analysis for wind farm development in Saudi Arabia. Energy 2017, 141, 1166-1176. [CrossRef]

29. Díaz-Cuevas, P. GIS-Based Methodology for Evaluating the Wind-Energy Potential of Territories: A Case Study from Andalusia (Spain). Energies 2018, 11, 2789. [CrossRef]

30. Mederos, A.M.; Padrón, J.M.; Lorenzo, A.F. An offshore wind atlas for the Canary Islands. Renew. Sustain. Energy Rev. 2011, 15, 612-620. [CrossRef]

31. Cradden, L.; Kalogeri, C.; Barrios, I.M.; Galanis, G.; Ingram, D.; Kallos, G. Multi-criteria site selection for offshore renewable energy platforms. Renew. Energy 2016, 87, 791-806. [CrossRef]

32. Magar, V.; Gross, M.; González-García, L. Offshore wind energy resource assessment under techno-economic and socialecological constraints. Ocean Coast. Manag. 2018, 152, 77-87. [CrossRef]

33. Moore, A.; Price, J.; Zeyringer, M. The role of floating offshore wind in a renewable focused electricity system for Great Britain in 2050. Energy Strateg. Rev. 2018, 22, 270-278. [CrossRef]

34. Rediske, G.; Burin, H.; Rigo, P.; Rosa, C.; Michels, L.; Siluk, J. Wind power plant site selection: A systematic review. Renew. Sustain. Energy Rev. 2021, 148, 111293. [CrossRef]

35. Majidi Nezhad, M.; Nastasi, B.; Groppi, D.; Lamagna, M.; Piras, G.; Astiaso Garcia, D. Green Energy Sources Assessment Using Sentinel-1 Satellite Remote Sensing. Front. Energy Res. 2021, 9, 777. [CrossRef] 
36. Bosilovich, M.; Lucchesi, R.; Suarez, M. MERRA-2: File Specification; Technical Report; NASA Goddard Space Flight Center: Greenbelt, MD, USA, 2016. Available online: https://gmao.gsfc.nasa.gov/pubs/docs/Bosilovich785.pdf (accessed on 30 November 2021).

37. Yue, C.D.; Chiu, Y.S.; Tu, C.C.; Lin, T.H. Evaluation of an Offshore Wind Farm by Using Data from the Weather Station, Floating LiDAR, Mast, and MERRA. Energies 2020, 13, 185. [CrossRef]

38. Santos, J.; Sakagami, Y.; Haas, R.; Passos, J.; Machuca, M.; Radünz, W.; Dias, E.; Lima, M. Wind speed evaluation of MERRA-2, ERA-interim and ERA-5 reanalysis data at a wind farm located in brazil. In Proceedings of the ISES Solar World Congress, Santiago de Chile, Chile, 4-7 November 2019.

39. Kim, H.G.; Kim, J.Y.; Kang, Y.H. Comparative Evaluation of the Third-Generation Reanalysis Data for Wind Resource Assessment of the Southwestern Offshore in South Korea. Atmosphere 2018, 9, 73. [CrossRef]

40. Jourdier, B. Evaluation of ERA5, MERRA-2, COSMO-REA6, NEWA and AROME to simulate wind power production over France. Adv. Sci. Res. 2020, 17, 63-77. [CrossRef]

41. Gruber, K.; Regner, P.; Wehrle, S.; Zeyringer, M.; Schmidt, J. Towards global validation of wind power simulations: A multicountry assessment of wind power simulation from MERRA-2 and ERA-5 reanalyses bias-corrected with the global wind atlas. Energy 2022, 238, 121520. [CrossRef]

42. Rabbani, R.; Zeeshan, M. Exploring the suitability of MERRA-2 reanalysis data for wind energy estimation, analysis of wind characteristics and energy potential assessment for selected sites in Pakistan. Renew. Energy 2020, 154, 1240-1251. [CrossRef]

43. Moraes, L.; Bussar, C.; Stoecker, P.; Jacqué, K.; Chang, M.; Sauer, D. Comparison of long-term wind and photovoltaic power capacity factor datasets with open-license. Appl. Energy 2018, 225, 209-220. [CrossRef]

44. Tammelin, B.; Vihma, T.; Atlaskin, E.; Badger, J.; Fortelius, C.; Gregow, H.; Horttanainen, M.; Hyvönen, R.; Kilpinen, J.; Latikka, J.; et al. Production of the Finnish wind atlas. Wind Energy 2013, 16, 19-35. [CrossRef]

45. Moher, D.; Liberati, A.; Tetzlaff, J.; Altman, D.G. Preferred reporting items for systematic reviews and meta-analyses: The PRISMA statement. Int. J. Surg. 2010, 8, 336-341. [CrossRef]

46. Rezaei, M.; Mostafaeipour, A.; Qolipour, M.; Tavakkoli-Moghaddam, R. Investigation of the optimal location design of a hybrid wind-solar plant: A case study. Int. J. Hydrog. Energy 2018, 43, 100-114. [CrossRef]

47. Solangi, Y.A.; Tan, Q.; Khan, M.W.A.; Mirjat, N.H.; Ahmed, I. The Selection ofWind Power Project Location in the Southeastern Corridor of Pakistan: A Factor Analysis, AHP, and Fuzzy-TOPSIS Application. Energies 2018, 11, 1940. [CrossRef]

48. Ali, S.; Lee, S.M.; Jang, C.M. Determination of the Most Optimal On-Shore Wind Farm Site Location Using a GIS-MCDM Methodology: Evaluating the Case of South Korea. Energies 2017, 10, 2072. [CrossRef]

49. Villacreses, G.; Gaona, G.; Martínez-Gómez, J.; Jijón, D.J. Wind farms suitability location using geographical information system (GIS), based on multi-criteria decision making (MCDM) methods: The case of continental Ecuador. Renew. Energy 2017, 109, 275-286. [CrossRef]

50. Kazak, J.; van Hoof, J.; Szewranski, S. Challenges in the wind turbines location process in Central Europe. The use of spatial decision support systems. Renew. Sustain. Energy Rev. 2017, 76, 425-433. [CrossRef]

51. Weiss, C.V.C.; Tagliani, P.R.A.; Espinoza, J.M.A.; de Lima, L.T.; Gandra, T.B.R. Spatial planning for wind farms: Perspectives of a coastal area in southern Brazil. Springer 2018, 20, 665-666. [CrossRef]

52. Sánchez-Lozano, J.; García-Cascales, M.; Lamata, M. GIS-based onshore wind farm site selection using Fuzzy Multi-Criteria Decision Making methods. Evaluating the case of Southeastern Spain. Appl. Energy 2016, 171, 86-102. [CrossRef]

53. Hofer, T.; Sunak, Y.; Siddique, H.; Madlener, R. Wind farm siting using a spatial Analytic Hierarchy Process approach: A case study of the Städteregion Aachen. Appl. Energy 2016, 163, 222-243. [CrossRef]

54. Watson, J.J.; Hudson, M.D. Regional Scale wind farm and solar farm suitability assessment using GIS-assisted multi-criteria evaluation. Landsc. Urban Plan. 2015, 138, 20-31. [CrossRef]

55. Schweizer, J.; Antonini, A.; Govoni, L.; Gottardi, G.; Archetti, R.; Supino, E.; Berretta, C.; Casadei, C.; Ozzi, C. Investigating the potential and feasibility of an offshore wind farm in the Northern Adriatic Sea. Appl. Energy 2016, 177, 449-463. [CrossRef]

56. Argin, M.; Yerci, V. Offshore wind power potential of the Black Sea region in Turkey. Int. J. Green Energy 2017, 14, 811-818. [CrossRef]

57. Wu, B.; Yip, T.L.; Xie, L.; Wang, Y. A fuzzy-MADM based approach for site selection of offshore wind farm in busy waterways in China. Ocean Eng. 2018, 168, 121-132. [CrossRef]

58. Vasileiou, M.; Loukogeorgaki, E.; Vagiona, D.G. GIS-based multi-criteria decision analysis for site selection of hybrid offshore wind and wave energy systems in Greece. Renew. Sustain. Energy Rev. 2017, 73, 745-757. [CrossRef]

59. Kim, T.; Park, J.I.; Maeng, J. Offshore wind farm site selection study around Jeju Island, South Korea. Renew. Energy 2016, 94, 619-628. [CrossRef]

60. Cavazzi, S.; Dutton, A. An Offshore Wind Energy Geographic Information System (OWE-GIS) for assessment of the UK's offshore wind energy potential. Renew. Energy 2016, 87, 212-228. [CrossRef]

61. Li, M.; Xu, Y.; Guo, J.; Li, Y.; Li, W. Application of a GIS-Based Fuzzy Multi-Criteria Evaluation Approach for Wind Farm Site Selection in China. Energies 2020, 13, 2426. [CrossRef]

62. Dhunny, A.; Doorga, J.; Allam, Z.; Lollchund, M.; Boojhawon, R. Identification of optimal wind, solar and hybrid wind-solar farming sites using fuzzy logic modelling. Energy 2019, 188, 116056. [CrossRef] 
63. Ali, S.; Jang, C.M. Selection of Best-Suited Wind Turbines for New Wind Farm Sites Using Techno-Economic and GIS Analysis in South Korea. Energies 2019, 12, 3140. [CrossRef]

64. Konstantinos, I.; Georgios, T.; Garyfalos, A. A Decision Support System methodology for selecting wind farm installation locations using AHP and TOPSIS: Case study in Eastern Macedonia and Thrace region, Greece. Energy Policy 2019, 132, $232-246$. [CrossRef]

65. Yan, H.; Wang, Y.; Zhou, X.; Liang, L.; Yin, Z.; Wang, W. Dynamic Thermal Rating of Overhead Transmission Lines Based on GRAPES Numerical Weather Forecast. J. Inf. Process. Syst. 2019, 15, 724-736. [CrossRef]

66. Gherboudj, I.; Ghedira, H. Assessment of solar energy potential over the United Arab Emirates using remote sensing and weather forecast data. Renew. Sustain. Energy Rev. 2016, 55, 1210-1224. [CrossRef]

67. Deng, H.; Li, Y.; Zhang, Y.; Zhou, H.; Cheng, P.; Wang, J.; Aqeel-Ashraf, M. Prediction of Hub Height Winds over the Plateau Terrain by using WRF /YSU/Noah and Statistical Forecast. Earth Sci. Res. J. 2017, 21, 37-43. [CrossRef]

68. Pyrchla, J.; Kowalewski, M.; Leyk-Wesolowska, M.; Pyrchla, K. Integration and Visualization of the Results of Hydrodynamic Models in the Maritime Network-Centric GIS of Gulf of Gdansk. In Proceedings of the 2016 Baltic Geodetic Congress (BGC Geomatics), Gdansk, Poland, 2-4 June 2016; pp. 159-164. [CrossRef]

69. Jiang, P.; Li, X.; Dong, Y. Research and Application of a New Hybrid Forecasting Model Based on Genetic Algorithm Optimization: A Case Study of Shandong Wind Farm in China. Math. Probl. Eng. 2015, 2015, 740490. [CrossRef]

70. Bellis Laura, M.; Verónica, A.; Andrés, L.; Juan, P.A.; Sofia, L.; Clemoveki, K.; Carlos, M.S. Design and implementation of an operational meteo fire risk forecast based on open source geospatial technology. In Proceedings of the 2015 IEEE International Geoscience and Remote Sensing Symposium (IGARSS), Milan, Italy, 26-31 July 2015. [CrossRef]

71. Adams, M.; Herbster, C. Using GIS Tools to Compare Hurricane Matthew and Irma Impacts to Florida Embry-Riddle Aeronautical University. 2018. Available online: https://commons.erau.edu/cgi/viewcontent.cgi?article=1269\&context=discovery-day (accessed on 30 November 2021).

72. Chang, P.C.; Yang, R.Y.; Lai, C.M. Potential of Offshore Wind Energy and Extreme Wind Speed Forecasting on the West Coast of Taiwan. Energies 2015, 8, 1685-1700. [CrossRef]

73. Siyal, S.H.; Mörtberg, U.; Mentis, D.; Welsch, M.; Babelon, I.; Howells, M. Wind energy assessment considering geographic and environmental restrictions in Sweden: A GIS-based approach. Energy 2015, 83, 447-461. [CrossRef]

74. Höltinger, S.; Salak, B.; Schauppenlehner, T.; Scherhaufer, P.; Schmidt, J. Austria's wind energy potential—A participatory modeling approach to assess socio-political and market acceptance. Energy Policy 2016, 98, 49-61. [CrossRef]

75. Pamučar, D.; Gigović, L.; Bajić, Z.; Janošević, M. Location Selection for Wind Farms Using GIS Multi-Criteria Hybrid Model: An Approach Based on Fuzzy and Rough Numbers. Sustainability 2017, 9, 1315. [CrossRef]

76. Morano, P.; Tajani, F.; Locurcio, M. GIS application and econometric analysis for the verification of the financial feasibility of roof-top wind turbines in the city of Bari (Italy). Renew. Sustain. Energy Rev. 2017, 70, 999-1010. [CrossRef]

77. Lotfi, R.; Mostafaeipour, A.; Mardani, N.; Mardani, S. Investigation of wind farm location planning by considering budget constraints. Int. J. Sustain. Energy 2018, 37, 799-817. [CrossRef]

78. Tsoutsos, T.; Tsitoura, I.; Kokologos, D.; Kalaitzakis, K. Sustainable siting process in large wind farms case study in Crete. Renew. Energy 2015, 75, 474-480. [CrossRef]

79. Pillai, A.C.; Chick, J.; Khorasanchi, M.; Barbouchi, S.; Johanning, L. Application of an offshore wind farm layout optimization methodology at Middelgrunden wind farm. Ocean Eng. 2017, 139, 287-297. [CrossRef]

80. Gimpel, A.; Stelzenmüller, V.; Grote, B.; Buck, B.H.; Floeter, J.; Núñez-Riboni, I.; Pogoda, B.; Temming, A. A GIS modelling framework to evaluate marine spatial planning scenarios: Co-location of offshore wind farms and aquaculture in the German EEZ. Mar. Policy 2015, 55, 102-115. [CrossRef]

81. Fetanat, A.; Khorasaninejad, E. A novel hybrid MCDM approach for offshore wind farm site selection: A case study of Iran. Ocean Coast. Manag. 2015, 109, 17-28. [CrossRef]

82. Wu, Y.; Zhang, J.; Yuan, J.; Geng, S.; Zhang, H. Study of decision framework of offshore wind power station site selection based on ELECTRE-III under intuitionistic fuzzy environment: A case of China. Energy Convers. Manag. 2016, 113, 66-81. [CrossRef]

83. Schallenberg-Rodríguez, J.; Montesdeoca, N.G. Spatial planning to estimate the offshore wind energy potential in coastal regions and islands. Practical case: The Canary Islands. Energy 2018, 143, 91-103. [CrossRef]

84. Sterl, S.; Liersch, S.; Koch, H.; van Lipzig, N.P.M.; Thiery, W. A new approach for assessing synergies of solar and wind power: implications for West Africa. Environ. Res. Lett. 2018, 13, 094009. [CrossRef]

85. Mahdy, M.; Bahaj, A.S. Multi criteria decision analysis for offshore wind energy potential in Egypt. Renew. Energy 2018, 118, 278-289. [CrossRef]

86. Mytilinou, V.; Lozano-Minguez, E.; Kolios, A. A Framework for the Selection of Optimum Offshore Wind Farm Locations for Deployment. Energies 2018, 11, 1855. [CrossRef]

87. Satir, M.; Murphy, F.; McDonnell, K. Feasibility study of an offshore wind farm in the Aegean Sea, Turkey. Renew. Sustain. Energy Rev. 2018, 81, 2552-2562. [CrossRef]

88. Astariz, S.; Iglesias, G. Selecting optimum locations for co-located wave and wind energy farms. Part I: The Co-Location Feasibility index. Energy Convers. Manag. 2016, 122, 589-598. [CrossRef]

89. Mekonnen, A.D.; Gorsevski, P.V. A web-based participatory GIS (PGIS) for offshore wind farm suitability within Lake Erie, Ohio. Renew. Sustain. Energy Rev. 2015, 41, 162-177. [CrossRef] 
90. Repetto, M.; Burlando, M.; Solari, G.; De Gaetano, P.; Pizzo, M. Integrated tools for improving the resilience of seaports under extreme wind events. Sustain. Cities Soc. 2017, 32, 277-294. [CrossRef]

91. Jin, X.; Wang, F.; Chen, L.; Li, J.; Zhao, W. Visualization of Storm Surge based on GIS. In Proceedings of the International Conference on Advances in Mechanical Engineering and Industrial Informatics, Zhengzhou, China, 11-12 April 2015. [CrossRef]

92. Latinopoulos, D.; Kechagia, K. A GIS-based multi-criteria evaluation for wind farm site selection. A regional scale application in Greece. Renew. Energy 2015, 78, 550-560. [CrossRef]

93. Atici, K.B.; Simsek, A.B.; Ulucan, A.; Tosun, M.U. A GIS-based Multiple Criteria Decision Analysis approach for wind power plant site selection. Util. Policy 2015, 37, 86-96. [CrossRef]

94. Vagiona, D.G.; Kamilakis, M. Sustainable Site Selection for Offshore Wind Farms in the South Aegean-Greece. Sustainability 2018, 10, 749. [CrossRef]

95. Noorollahi, Y.; Yousefi, H.; Mohammadi, M. Multi-criteria decision support system for wind farm site selection using GIS Sustain.Energy Technol. Assess. 2016, 13, 38-50. [CrossRef]

96. Chen, W.; Zhu, Y.; Yang, M.; Yuan, J. Optimal Site Selection of Wind-Solar Complementary Power Generation Project for a Large-Scale Plug-In Charging Station. Sustainability 2017, 9, 1994. [CrossRef]

97. Rao, M.; Sridharamurthy, K.; Ayappan, S.; Sreeram, G.; Nayak, J.; Shankar, M.; Krishnappa, D. How Farmers Benefit from Integration of EO, Meteorological, Positioning and Field Data in an Analytics Engine-The AGRI-GIS Example of S Odisha, India. 2018. Available online: http:/ / eprints.nias.res.in/id/eprint/1739 (accessed on 30 November 2021 ).

98. Al-Yahyai, S.; Charabi, Y. Assessment of large-scale wind energy potential in the emerging city of Duqm (Oman). Renew. Sustain. Energy Rev. 2015, 47, 438-447. [CrossRef]

99. ECMWF. European Centre for Medium-Range Weather Forecasts. 2020. Available online: https://www.ecmwf.int/ (accessed on 30 November 2021).

100. Ntoka, C. Offshore Wind Park Sitting and Micro-Sitting in Petalioi Gulf, Greece. 2013. Available online: https://www. semanticscholar.org/ (accessed on 30 November 2021).

101. Chaouachi, A.; Covrig, C.F.; Ardelean, M. Multi-criteria selection of offshore wind farms: Case study for the Baltic States. Energy Policy 2017, 103, 179-192. [CrossRef]

102. Nagababu, G.; Kachhwaha, S.S.; Savsani, V. Estimation of technical and economic potential of offshore wind along the coast of India. Energy 2017, 138, 79-91. [CrossRef]

103. Davò, F.; Alessandrini, S.; Sperati, S.; Delle Monache, L.; Airoldi, D.; Vespucci, M.T. Post-processing techniques and principal component analysis for regional wind power and solar irradiance forecasting. Sol. Energy 2016, 134, 327-338. [CrossRef]

104. Huld, T.; Amillo, A.M.G. Estimating PV Module Performance over Large Geographical Regions: The Role of Irradiance, Air Temperature, Wind Speed and Solar Spectrum. Energies 2015, 8, 5159-5181. [CrossRef]

105. Donida Labati, R.; Genovese, A.; Piuri, V.; Scotti, F.; Sforza, G. A Decision Support System for Wind Power Production. IEEE Trans. Syst. Man Cybern. Syst. 2019, 50, 290-304. [CrossRef]

106. McKenna, R.; Hollnaicher, S.; vd Leye, P.O.; Fichtner, W. Cost-potentials for large onshore wind turbines in Europe. Energy 2015, 83, 217-229. [CrossRef]

107. Majidi Nezhad, M.; Groppi, D.; Marzialetti, P.; Fusilli, L.; Laneve, G.; Cumo, F.; Garcia, D.A. Wind energy potential analysis using Sentinel-1 satellite: A review and a case study on Mediterranean islands. Renew. Sustain. Energy Rev. 2019, 109, 499-513. [CrossRef]

108. Nagababu, G.; Kachhwaha, S.S.; Naidu, N.K.; Savsani, V. Application of reanalysis data to estimate offshore wind potential in EEZ of India based on marine ecosystem considerations. Energy 2017, 118, 622-631. [CrossRef]

109. NOAA. Global Marine Data Map. 2020. Available online: https://gis.ncdc.noaa.gov/maps/ncei/marine (accessed on 30 November 2021).

110. Waewsak, J.; Landry, M.; Gagnon, Y. Offshore wind power potential of the Gulf of Thailand. Renew. Energy 2015, 81, 609-626. [CrossRef]

111. Shahriari, M.; Cervone, G.; Clemente-Harding, L.; Delle Monache, L. Using the analog ensemble method as a proxy measurement for wind power predictability. Renew. Energy 2020, 146, 789-801. [CrossRef]

112. Grassi, S.; Veronesi, F.; Schenkel, R.; Peier, C.; Neukom, J.; Volkwein, S.; Martin, R.; Hurni, L. Mapping of the global wind energy potential using open source GIS data. In Proceedings of the 2nd International Conference on Energy and Environment, Guimarães, Portugal, 18-19 June 2015; pp. 647-653.

113. Wing, O.E.; Sampson, C.C.; Bates, P.D.; Quinn, N.; Smith, A.M.; Neal, J.C. A flood inundation forecast of Hurricane Harvey using a continental-scale 2D hydrodynamic model. J. Hydrol. X 2019, 4, 100039. [CrossRef]

114. Unger, J.D. Analysis of Hurricane Track Forecast Accuracy during the 2018 Season. 2019. Available online: https://trace. tennessee.edu/cgi/viewcontent.cgi?article=1394\&context=pursuit (accessed on 30 November 2021)

115. New European Wind Atlas. Wind Atlas data from European Wind Atlas Project. 2020. Available online: https://map. neweuropeanwindatlas.eu/ (accessed on 30 November 2021).

116. Vortex. Wind Speed Maps. 2020. Available online: https://interface.vortexfdc.com/ (accessed on 30 November 2021).

117. Renewables.Ninja. World Geographic Information Wind Speed. 2020. Available online: https://www.renewables.ninja/ (accessed on 30 November 2021). 
118. WindFinder. Wind Predictions. 2020. Available online: https://es.windfinder.com/\#8/43.2932/-7.8387/ report (accessed on 30 November 2021).

119. Global Wind Atlas. Wind Speed Maps, by Vortex. 2020. Available online: https://globalwindatlas.info/area/Spain/ (accessed on 30 November 2021).

120. Değirmenci, S.C.; Bingöl, F.; Sofuoglu, S.C. MCDM analysis of wind energy in Turkey: Decision making based on environmental impact. Environ. Sci. Pollut. Res. 2018, 25, 19753-19766. [CrossRef]

121. Enevoldsen, P.; Permien, F.H.; Bakhtaoui, I.; von Krauland, A.K.; Jacobson, M.Z.; Xydis, G.; Sovacool, B.K.; Valentine, S.V.; Luecht, D.; Oxley, G. How much wind power potential does europe have? Examining european wind power potential with an enhanced socio-technical atlas. Energy Policy 2019, 132, 1092-1100. [CrossRef]

122. Bosch, J.; Staffell, I.; Hawkes, A.D. Temporally-explicit and spatially-resolved global onshore wind energy potentials. Energy 2017, 131, 207-217. [CrossRef]

123. Bosch, J.; Staffell, I.; Hawkes, A.D. Temporally explicit and spatially resolved global offshore wind energy potentials. Energy 2018, 163, 766-781. [CrossRef]

124. NREL. Computational Wind Studies. 2020. Available online: https://www.nrel.gov/ (accessed on 30 November 2021).

125. Sarpong, D.; Baffoe, P.E. Selecting Suitable Sites for Wind Energy Development in Ghana. Ghana Min. J. 2016, 16, 8-20. [CrossRef]

126. Ahmed, A.; Khalid, M. Multi-step Ahead Wind Forecasting Using Nonlinear Autoregressive Neural Networks. Energy Procedia 2017, 134, 192-204. Sustainability in Energy and Buildings 2017: Proceedings of the Ninth KES International Conference, Chania, Greece, 5-7 July 2017. [CrossRef]

127. Anwarzai, M.A.; Nagasaka, K. Utility-scale implementable potential of wind and solar energies for Afghanistan using GIS multi-criteria decision analysis. Renew. Sustain. Energy Rev. 2017, 71, 150-160. [CrossRef]

128. $\mathrm{FiNO}_{3}$. Baltic and North Sea Maritime Platform. 2020. Available online: https://www.fino3.de/en/about.html (accessed on 30 November 2021).

129. Nie, B.; Li, J. Technical potential assessment of offshore wind energy over shallow continent shelf along China coast. Renew. Energy 2018, 128, 391-399. [CrossRef]

130. NasaPowerLarc. Weather Forecasts. 2020. Available online: https://power.larc.nasa.gov/data-access-viewer/ (accessed on 30 November 2021).

131. Mentis, D.; Hermann, S.; Howells, M.; Welsch, M.; Siyal, S.H. Assessing the technical wind energy potential in Africa a GIS-based approach. Renew. Energy 2015, 83, 110-125. [CrossRef]

132. Jangid, J.; Bera, A.K.; Joseph, M.; Singh, V.; Singh, T.; Pradhan, B.; Das, S. Potential zones identification for harvesting wind energy resources in desert region of India-A multi criteria evaluation approach using remote sensing and GIS. Renew. Sustain. Energy Rev. 2016, 65, 1-10. [CrossRef]

133. Mentis, D.; Siyal, S.H.; Korkovelos, A.; Howells, M. A geospatial assessment of the techno-economic wind power potential in India using geographical restrictions. Renew. Energy 2016, 97, 77-88. [CrossRef]

134. Gualtieri, G. Reliability of ERA5 Reanalysis Data for Wind Resource Assessment: A Comparison against Tall Towers. Energies 2021, 14, 4169. [CrossRef]

135. Muñoz Sabater, J. ERA5-Land Hourly Data from 1981 to Present. Copernicus Climate Change Service (C3S) Climate Data Store (CDS). 2020. Available online: https:/ / cds.climate.copernicus.eu/cdsapp\#!/dataset/10.24381/cds.e2161bac?tab=overview (accessed on 30 November 2021) [CrossRef]

136. Ruiz, P.; Nijs, W.; Tarvydas, D.; Sgobbi, A.; Zucker, A.; Pilli, R.; Jonsson, R.; Camia, A.; Thiel, C.; Hoyer-Klick, C.; et al. ENSPRESO-An open, EU-28 wide, transparent and coherent database of wind, solar and biomass energy potentials. Energy Strateg. Rev. 2019, 26, 100379. [CrossRef]

137. Gonzalez Aparicio, I.; Huld, T.; Careri, F.; Monforti, F.; Zucker, A. EMHIRES dataset Part II: Solar power generation. In European Meteorological Derived HIgh Resolution RES Generation Time Series for Present and Future Scenarios. Part II: PV Generation Using the PVGIS Model; Publications Office of the European Union: Luxembourg, 2017.

138. NOAA. Global Climate Station Summaries. 2020. Available online: https://www7.ncdc.noaa.gov/CDO/cdoselect.cmd (accessed on 30 November 2021).

139. Aymamí, J.; García, A.; Lacave, O.; Lledó, L.; Mayo, M.; Parés, S. Resource Analysis. Spanish Wind Atlas. Technical Study PER 2011-2020; IDAE: Madrid, Spain, 2011. Available online: https://www.idae.es/uploads/documentos/documentos_11227_e4 _atlas_eolico_A_9b90ff10.pdf (accessed on 30 November 2021).

140. Witha, B.; Hahmann, A.; Sile, T.; Dörenkämper, M.; Ezber, Y.; García-Bustamante, E.; González-Rouco, J.F.; Leroy, G.; Navarro, J. WRF Model Sensitivity Studies and Specifications for the NEWA Mesoscale Wind Atlas Production Runs; NEWA-New European Wind Atlas: Barcelona, Spain, 2019. [CrossRef]

141. Tine, B.; Yalamarthy, K.P.; Elsabbagh, F.; Hyesoon, K. Vortex: Extending the RISC-V ISA for GPGPU and 3D-Graphics. In Proceedings of the MICRO-54: 54th Annual IEEE/ACM International Symposium on Microarchitecture, Athens, Greece, 18-22 October 2021; pp. 754-766.

142. Staffell, I.; Pfenninger, S. Using bias-corrected reanalysis to simulate current and future wind power output. Energy 2016, 114, 1224-1239. [CrossRef]

143. ESMAP. Assistance Program for the Energy Sector Management. 2020. Available online: https://www.esmap.org/ (accessed on 30 November 2021). 
144. DTU. Technical University of Denmark. 2020. Available online: https:/ / www.dtu.dk/english (accessed on 30 November 2021).

145. Kim, J.Y.; Oh, K.Y.; Kim, M.S.; Kim, K.Y. Evaluation and characterization of offshore wind resources with long-term met mast data corrected by wind lidar. Renew. Energy 2019, 144, 41-55. [CrossRef]

146. Shen, S.; Leptoukh, G.; Loboda, T.; Csiszar, I.; Romanov, P.; Gerasimov, I. The NASA NEESPI data portal to support studies of climate and environmental changes in non-boreal Europe. In Regional Aspects of Climate-Terrestrial-Hydrologic Interactions in Non-boreal Eastern Europe; Springer: Dordrecht, The Netherlands , 2009; pp. 9-16.

147. Abdelaal, A.; Abbas, E.A.; Beheary, M.S. Assessment of dust major ions and suspended heavy metal contents in atmospheric particulate matter of Port Said city, Egypt. Arab. J. Geosci. 2021, 14, 1-17. [CrossRef]

148. Ledari, D.G.; Hamidi, M.; Shao, Y. Numerical simulation of the 18 February 2017 frontal dust storm over southwest of Iran using WRF-Chem, satellite imagery, and PM10 concentrations. J. Arid Environ. 2022, 196, 104637. [CrossRef]

149. Wei, J.C.; Ichoku, C.M.; Petrenko, M.; Yang, W.; Albayrak, A.; Zhao, P.; Johnson, J.E.; Kempler, S. NASA GES DISC Aerosol analysis and visualization services. AGU Fall Meet. Abstr. 2015, 2015, A31D-0098.

150. Tariq, S.; Qayyum, F.; Ul-Haq, Z.; Mehmood, U. Long-term spatiotemporal trends in aerosol optical depth and its relationship with enhanced vegetation index and meteorological parameters over South Asia. Environ. Sci. Pollut. Res. 2022, 1-18. [CrossRef]

151. Bhadauriya, S.; Chaudhary, N.; Mamatha, S.; Ray, S. Relationship Between Rice Residue Burning and Increasing Air Pollution in North-West India. Int. Arch. Photogramm. Remote Sens. Spat. Inf. Sci. 2020, 43, 1423-1430. [CrossRef]

152. Jury, M.R. Meteorology of air pollution in Los Angeles. Atmos. Pollut. Res. 2020, 11, 1226-1237. [CrossRef]

153. Sharma, R.; Sachdeva, K.; Sharma, A.R. Surface ozone in Indian urban region. In Asian Atmospheric Pollution; Elsevier: Amsterdam, The Netherlands, 2022; pp. 323-333.

154. Jamali, A.A.; Kalkhajeh, R.G.; Randhir, T.O.; He, S. Modeling relationship between land surface temperature anomaly and environmental factors using GEE and Giovanni. J. Environ. Manag. 2022, 302, 113970. [CrossRef] [PubMed]

155. Arribas, L.; Lechón, Y.; Perula, A.; Domínguez, J.; Ferres, M.; Navarro, J.; Zarzalejo, L.F.; García Barquero, C.; Cruz, I. Review of Data and Data Sources for the Assessment of the Potential of Utility-Scale Hybrid Wind-Solar PV Power Plants Deployment, under a Microgrid Scope. Energies 2021, 14, 7434. [CrossRef]

156. Polo, J.; Bernardos, A.; Navarro, A.; Fernandez-Peruchena, C.; Ramírez, L.; Guisado, M.V.; Martínez, S. Solar resources and power potential mapping in Vietnam using satellite-derived and GIS-based information. Energy Convers. Manag. 2015, 98, 348-358. [CrossRef]

157. Grassi, S.; Chokani, N.; Abhari, R.S. Large scale technical and economical assessment of wind energy potential with a GIS tool: Case study Iowa. Energy Policy 2012, 45, 73-85. [CrossRef]

158. Gielen, D.; Gorini, R.; Wagner, N.; Leme, R.; Gutierrez, L.; Prakash, G.; Asmelash, E.; Janeiro, L.; Gallina, G.; Vale, G.; et al. Global Energy Transformation: A Roadmap to 2050. 2019. Available online: https://www.irena.org/-/media/Files/IRENA/Agency/ Publication/2019/Apr/IRENA_Global_Energy_Transformation_2019.pdf (accessed on 30 November 2021).

159. Spyridonidou, S.; Vagiona, D.G.; Loukogeorgaki, E. Strategic Planning of Offshore Wind Farms in Greece. Sustainability 2020, 12, 905. [CrossRef]

160. Enevoldsen, P.; Permien, F.H. Mapping the Wind Energy Potential of Sweden: A Sociotechnical Wind Atlas. J. Renew. Energy 2018, 2018, 1650794. [CrossRef]

161. de Santoli, L.; Mancini, F.; Astiaso Garcia, D. A GIS-based model to assess electric energy consumptions and usable renewable energy potential in Lazio region at municipality scale. Sustain. Cities Soc. 2019, 46, 101413. [CrossRef]

162. Gigović, L.; Pamučar, D.; Božanić, D.; Ljubojević, S. Application of the GIS-DANP-MABAC multi-criteria model for selecting the location of wind farms: A case study of Vojvodina, Serbia. Renew. Energy 2017, 103, 501-521. [CrossRef]

163. Grau, L.; Jung, C.; Schindler, D. On the Annual Cycle of Meteorological and Geographical Potential of Wind Energy: A Case Study from Southwest Germany. Sustainability 2017, 9, 1169. [CrossRef] 